FRANCINE ANDREA DE RUSSO

Utilização de ácidos orgânicos, mananoligossacarídeos e extratos de plantas na alimentação de frangos de corte 


\section{Utilização de ácidos orgânicos, mananoligossacarídeos e extratos de plantas na alimentação de frangos de corte}

\begin{abstract}
Dissertação apresentada ao Programa de Pós- Graduação em Nutrição e Produção Animal da Faculdade de Medicina Veterinária e Zootecnia da Universidade de São Paulo para obtenção do título de mestre em Ciências.
\end{abstract}

\section{Departamento:}

Nutrição e Produção Animal

Área de concentração:

Nutrição Animal

Orientador:

Prof. Dr. Ricardo de Albuquerque 
Autorizo a reprodução parcial ou total desta obra, para fins acadêmicos, desde que citada a fonte.

DADOS INTERNACIONAIS DE CATALOGAÇÃO-NA-PUBLICAÇÃO

(Biblioteca Virginie Buff D’Ápice da Faculdade de Medicina Veterinária e Zootecnia da Universidade de São Paulo)

Russo, Francine Andrea de

Utilização de ácidos orgânicos, mananoligossacarídeos e extratos de plantas na alimentação de frangos de corte / Francine Andrea de Russo. -- 2011.

$65 \mathrm{f}$. : il.

Dissertação (Mestrado) - Universidade de São Paulo. Faculdade de Medicina Veterinária e Zootecnia. Departamento de Nutrição e Produção Animal, Pirassununga, 2011.

Programa de Pós-Graduação: Nutrição e Produção Animal.

Área de concentração: Nutrição e Produção Animal.

Orientador: Prof. Dr. Ricardo de Albuquerque.

1. Aditivos alternativos. 2. Antibiótico. 3. Avicultura. 4. Desempenho. 5. Produção. 6. Vilosidades. I. Título. 


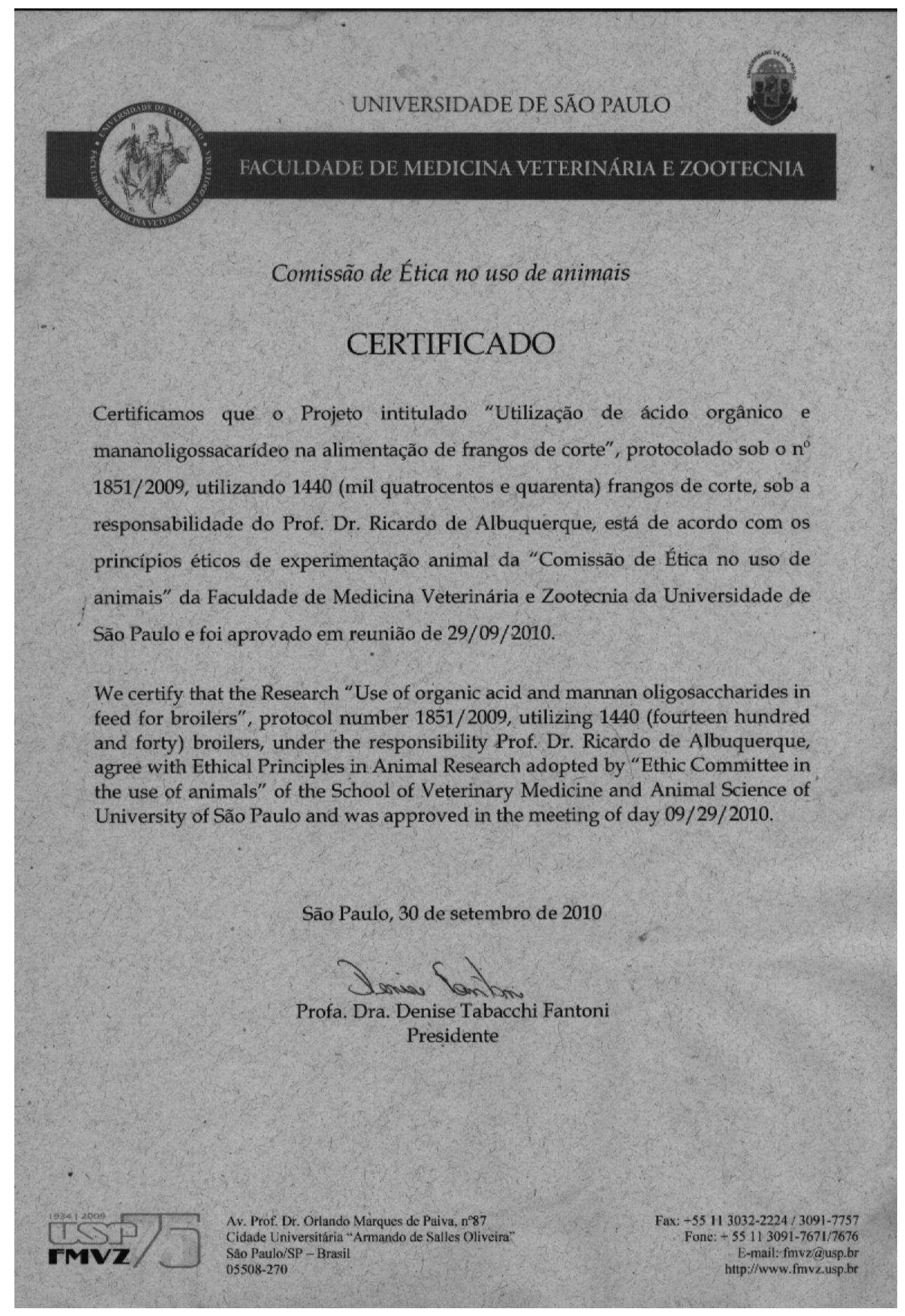




\section{FOLHA DE AVALIAÇÃO}

Nome: RUSSO, Francine Andrea

Título: Utilização de ácidos orgânicos, mananoligossacarídeos e extratos de plantas na alimentação de frangos de corte.

Dissertação apresentada ao Programa de Pós- Graduação em Nutrição e Produção Animal da Faculdade de Medicina Veterinária e Zootecnia da Universidade de São Paulo para obtenção do título de mestre em Ciências.

Aprovado em:

\section{Banca Examinadora}

| Prof. Dr. Instituição:

Assinatura: Julgamento:

| Prof. Dr. Instituição:

Assinatura: Julgamento:

| Prof. Dr. Instituição:

Assinatura: Julgamento: 
Dedico a Deus, minha família e amigos. 


\section{AGRADECIMENTOS}

A Deus por estar comigo sempre, me dando força e saúde.

Ao professor Dr. Ricardo de Albuquerque pela paciência, calma, amizade e orientação nestes anos de convivência.

Ao professor Dr. Lúcio Francelino Araujo, por toda ajuda na elaboração deste trabalho, paciência e conselhos.

Aos funcionários do aviário, Edinho e China, pela disposição e contribuição durante o experimento.

A CAPES, pela concessão de bolsa.

Ao VNP- Departamento de Nutrição e Produção Animal, em especial para Alessandra pela delicadeza e educação.

As empresas Degussa, Nutriacid e ICC pelos produtos fornecidos.

À todos colegas de pós- graduação, em especial João Guilherme, Maria Fernanda, Nayara, Pedro e Maria Tereza pela ajuda em todos os momentos do experimento, e também ao Jeferson que foi fundamental na parte final deste trabalho.

A minha mãe, irmão e avó que sem eles não estaria aqui, pelo carinho, amor, apoio e incentivo em todos os momentos. E ao meu namorado pelos conselhos, carinho e amor.

As minhas queridas amigas Nathalie, Viviane, Caroline e Ariana, que são um exemplo de amizade, companheirismo e afeto.

A Ester e Paulo César (PC) pela ajuda, risadas e amizade que me concederam.

Aos responsáveis pelo Laboratório de Morfofisiologia Molecular e Desenvolvimento pertencente ao Departamento de Ciências Básicas da Faculdade de Zootecnia e Engenharia de Alimentos da Universidade de São Paulo, por disponibilizar os equipamentos necessários à morfometria intestinal. 


\section{RESUMO}

RUSSO, F. A. Utilização de ácidos orgânicos, mananoligossacarídeos e extratos de plantas na alimentação de frangos de corte. [Use of organic acids, plant extracts and MOS fed to broilers]. 2011. 65 f. Dissertação (Mestrado em Ciências) - Faculdade de Medicina Veterinária e Zootecnia, Universidade de São Paulo, Pirassununga, 2011.

Foram utilizados 1140 pintos de corte, machos, da linhagem comercial Cobb criados de 1 a 42 dias de idade e alojados em um galpão experimental. Foram testados seis tratamentos, com seis repetições de 40 aves, adotando-se um delineamento experimental inteiramente ao acaso. Os tratamentos foram: T1 - Controle; T2 - Antibiótico (Bacitracina de Zinco); T3 - MOS; T4- Ácidos Orgânicos; T5 - MOS + Ácidos Orgânicos, T6- Extratos de Plantas. Os parâmetros de desempenho avaliados foram (consumo de ração, ganho de peso, conversão alimentar e mortalidade), e morfometria intestinal.Os dados foram submetidos à análise de variância e, para a comparação das médias foi utilizado contrastes ortogonais, com um nível de $5 \%$ de probabilidade. Houve efeito significativo $(\mathrm{p}<0,05)$ tanto para as varáveis de desempenho em todos os períodos analisados, como para as variáveis de morfometria intestinal. Os aditivos alternativos substituíram o antibiótico de forma eficiente em todas as fases de criação, tanto para índices zootécnicos quanto para morfometria intestinal, sendo uma eficiente alternativa de uso.

Palavras-chave: Aditivos alternativos. Antibiótico. Avicultura. Desempenho. Produção. Vilosidades. 


\begin{abstract}
RUSSO, F. A. Use of organic acids, plant extracts and MOS fed to broilers. [Utilização de ácidos orgânicos, mananoligossacarídeos e extratos de plantas na alimentação de frangos de corte]. 2011.65 f. Dissertação (Mestrado em Ciências) - Faculdade de Medicina Veterinária e Zootecnia, Universidade de São Paulo, Pirassununga, 2011.

Were used in 1140 chicks, male, commercial line Cobb raised from 1 to 42 days old and housed in an experimental barn. We tested six treatments with six replicates of 40 birds, adopting a completely randomized experimental design. The treatments were: T1 - control, T2 - Antibiotic (Bacitracin Zinc), T3 - MOS-Organic Acids T4, T5 - MOS + Organic Acids, Plant Extract-T6. The performance parameters evaluated were (feed intake, weight gain, feed conversion and mortality), and morphometry intestinal.Os data were subjected to analysis of variance and, for comparison of means was used orthogonal contrasts, with a level of $5 \%$ Probability. Significant effects $(p<0.05)$ for both variables of performance in all study periods, as for the variables of intestinal morphology. The additives have replaced the alternative antibiotic efficiently at all stages of creation, both in biological indices as in intestinal morphology, with an efficient alternative use.
\end{abstract}

Keywords: Additive alternative. Antibiotic. Performance. Poultry. Production. Villi. 


\section{LISTA DE ILUSTRAÇÕES}

\section{CAPÍTULO III}

Figura 1 - Bloco de parafina com os segmentos intestinais do jejuno 54

Figura 2 - Máquina para cortes histológicos 54

Figura 3 - Leitura da altura de vilos e profundidade de cripta no jejuno aos 35 dias de idade. 55

Figura 4 - Leitura da altura de vilos e profundidade de cripta no íleo aos 42 dias de idade. 56 


\section{LISTA DE TABELAS}

\section{CAPÍtULO II}

Tabela 1 - Médias das temperaturas nos diferentes períodos experimentais ..................... 31

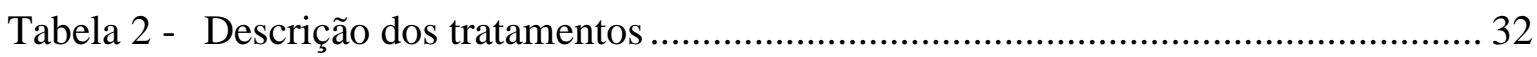

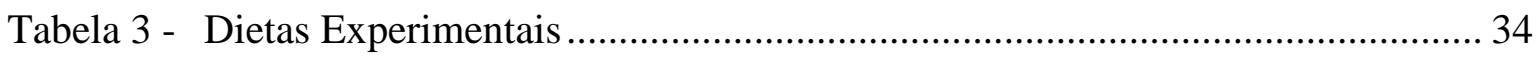

Tabela 4 - Esquema de contrastes dos efeitos entre os tratamentos ................................ 36

Tabela 5 - Médias dos tratamentos para consumo de ração (CR), ganho de peso (GP), conversão alimentar (CA), mortalidade (M), os contrastes e níveis de significância para cada variável dos período de 1 a 21; 22 a 35; 36 a 42 e 1 a 42 dias de idade.

\section{CAPÍTULO III}

Tabela 6 - Altura de vilos e profundidade de cripta do duodeno, jejuno e íleo e os contrastes e os níveis de significância para cada variável aos 21, 35 e 42 dias de idade 


\section{LISTA DE ABREVIATURAS E SIGLAS}

\begin{tabular}{|c|c|}
\hline Alt. & altura \\
\hline $\mathrm{cm}$ & centímetros \\
\hline $\mathrm{CV}$ & Coeficiente de Variação \\
\hline CR & Consumo de Ração \\
\hline $\mathrm{CA}$ & Conversão Alimentar \\
\hline DB & Dieta Basal \\
\hline$\mu \mathrm{m}$ & micrômetro \\
\hline GP & ganho de peso \\
\hline $\mathrm{g}$ & grama \\
\hline $\mathrm{m}^{2}$ & metro quadrado \\
\hline$\mu \mathrm{m}$ & micrômetro \\
\hline M & mortalidade \\
\hline MOS & mananoligossacarídeos \\
\hline Prof. & profundidade \\
\hline SAS & Statistical Analisys System \\
\hline ton & tonelada \\
\hline
\end{tabular}




\section{SUMÁRIO}

\section{CAPÍTULO I}

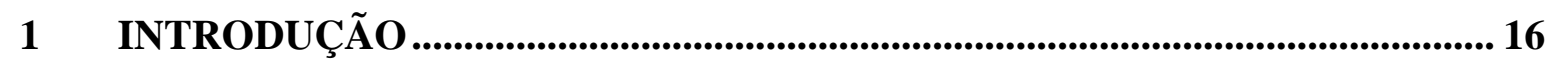

2 OBJETIVO E HIPÓTESE.................................................................................. 17

3 REVISÃO DE LITERATURA _........................................................................ 18

3.1 CONSIDERAÇÕES INICIAIS: ADITIVOS ALTERNATIVOS EM

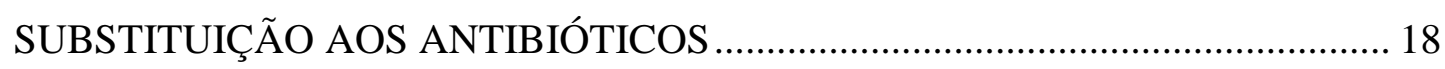

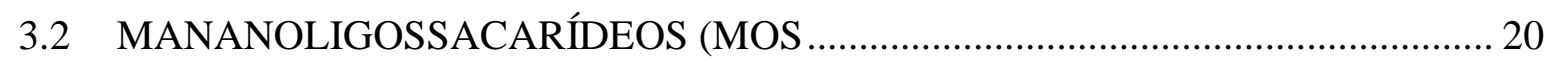

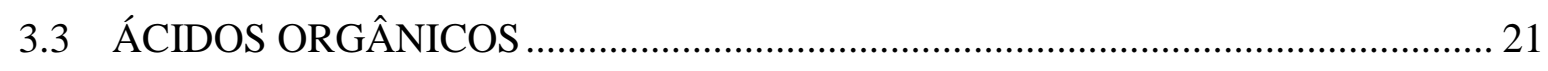

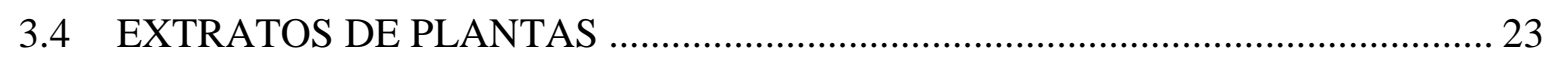

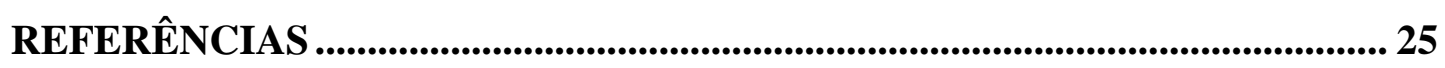

CAPÍTULO II - UTILIZAÇÃO DE ÁCIDOS ORGÂNICOS, MOS E EXTRATOS DE PLANTAS SOBRE O DESEMPENHO DE FRANGOS DE CORTE

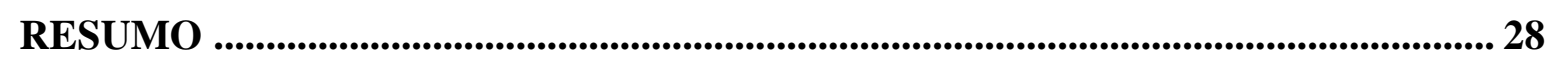

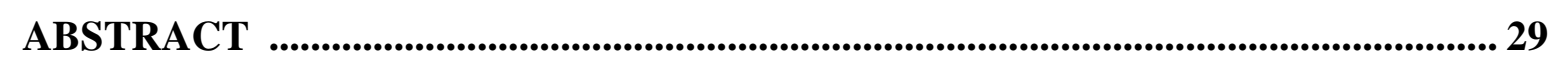

$4 \quad$ INTRODUÇÃO ........................................................................................................ 30

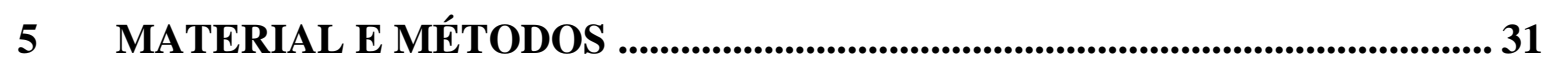

5.1 LOCAL, INSTALAÇÕES E PERÍODO EXPERIMENTAL ……………………..... 31

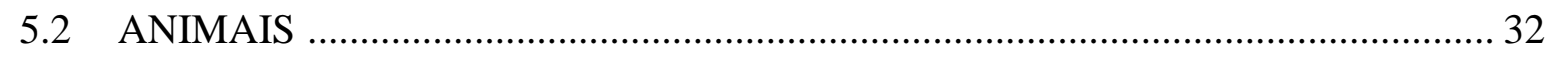

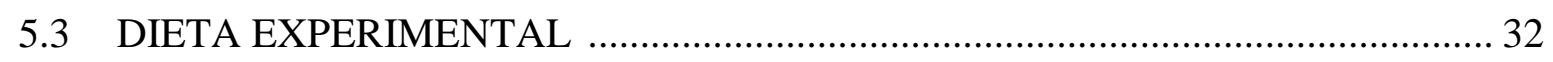

5.4 DELINEAMNETO EXPERIMENTAL E TRATAMENTOS …………………...... 32

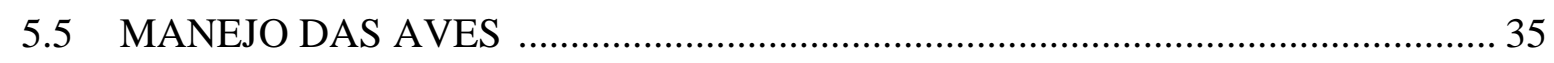

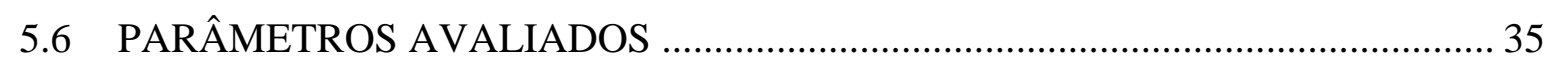

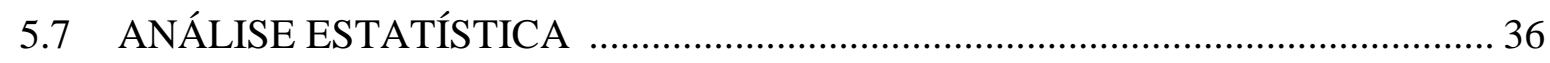




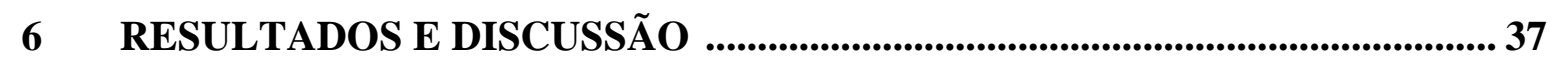

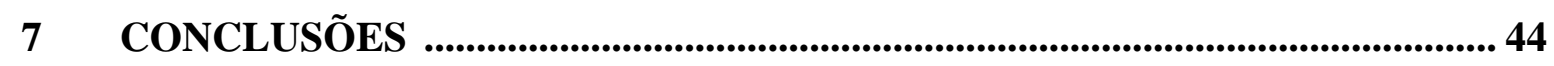

REFERÊNCIAS ..................................................................................................... 45

CAPÍTULO III - UTILIZAÇÃO DE ÁCIDOS ORGÂNICOS, MOS E EXTRATOS DE PLANTAS SOBRE A MORFOMETRIA INTESTINAL DE FRANGOS DE CORTE

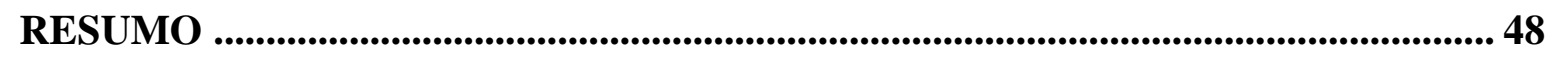

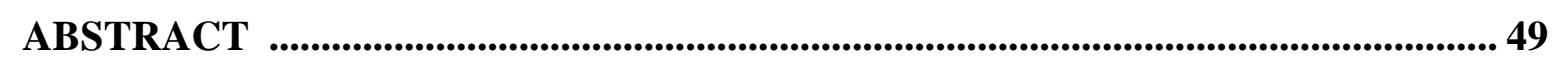

8 INTRODUÇÃO ............................................................................................50

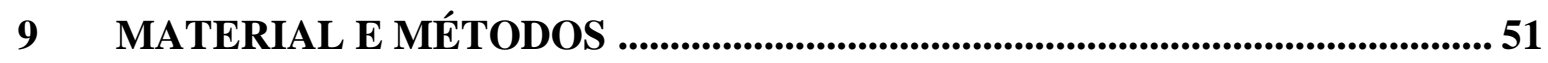

9.1 LOCAL, INSTALAÇÕES E PERÍODO EXPERIMENTAL …………………….... 51

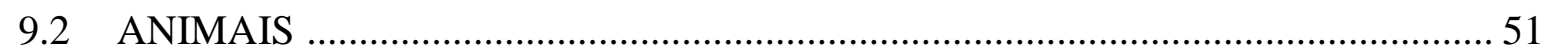

9.3 DIETA EXPERIMENTAL, DELINEAMENTO E TRATAMENTOS ………….....51

9.4 MANEJO DOS ANIMAIS ………………………..................................... 52

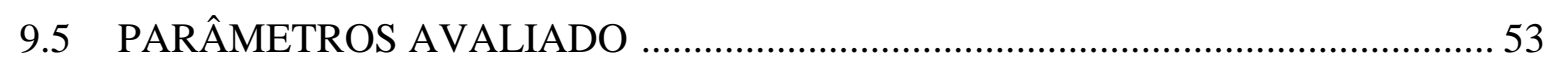

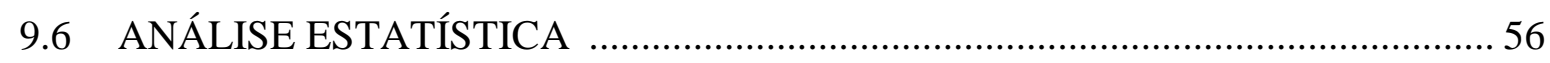

10 RESULTADOS E DISCUSSÃO ................................................................57

11 CONCLUSÕES ........................................................................................... 63

REFERÊNCIAS ................................................................................................6 64 
CAPÍTULO I 


\section{INTRODUÇÃO}

A avicultura tem um lugar de destaque na economia do país, pois hoje possui um dos mais modernos sistemas de produção, gerando inúmeros empregos e renda. Este desenvolvimento se dá graças aos avanços tecnológicos principalmente na nutrição (MURAROLLI, 2008).

Albuquerque (2005), afirma que em alguns países da Comunidade Européia foram feitas pesquisas que mostram que após a proibição ao uso de antibióticos como promotores de crescimento, houve uma perda de cerca de 176 milhões de dólares/ano na produção de carne de frango e 30 milhões para produção de ovos.

Torna-se evidente, portanto, a necessidade de estudos de produtos alternativos que possam substituir os antibióticos na alimentação animal, sem causar perdas de produtividade e qualidade de desempenho.

Algumas alternativas ao uso de antibióticos estão sendo usadas e é crescente o uso de aditivos na nutrição animal. Os aditivos são utilizados na produção animal com os objetivos de aumentar as taxas de crescimento e sobrevivência por parte do animal, melhorar a saúde do trato gastrintestinal e a eficiência alimentar, poupar energia e reduzir as cargas patogênicas, minimizando o impacto ambiental pela redução da transmissão de patógenos via alimentos (FLEMMING, 2005).

Entre os diversos aditivos não-nutrientes utilizados em rações para aves, destacam-se, os prebióticos, os probióticos, os ácidos orgânicos e os fitoterápicos. 


\section{OBJETIVO E HIPÓTESE}

O objetivo deste trabalho foi avaliar o impacto da utilização de mananoligossacarídeo (MOS), ácidos orgânicos (e a junção deles), e extratos de plantas em substituição ao promotor de crescimento (antibiótico) em dietas tradicionais da avicultura de corte, sobre o desempenho (ganho de peso, consumo de ração, conversão alimentar e mortalidade), e também na morfometria intestinal.

A hipótese é que os aditivos podem ser uma importante ferramenta em substituição ao antibiótico nas rações para frangos de corte, pois não promovem perdas no desempenho das aves quando comparados ao mesmo e muitas vezes trazem resultados superiores para os índices zootécnicos e morfometria intestinal. 


\section{REVISÃO DE LITERATURA}

3.1 CONSIDERAÇÕES INICIAIS: Aditivos alternativos em substituição aos antibióticos.

Através da modernização na área da genética, nutrição e manejo das aves, tem-se conseguido grandes avanços na cadeia produtiva de frangos de corte. Estes avanços reduzem custos e aumentam a competitividade do frango brasileiro no cenário mundial (SARCINELLI et al., 2007). Com isso a produção de frango de corte chegou a 499,350 mil/ton em janeiro de 2011 e a produção total de carne de frango a 1.048,7 mil/ton, sendo 341,0 mil/ton para a exportação e 707,6 mil/ton para a oferta interna em março de 2011. Colocando o Brasil em primeiro lugar nas exportações mundiais (AVISITE, 2011).

A alimentação animal apresenta hoje o maior gasto dentro da produção, sendo responsável na criação de aves comerciais por $70 \%$ do custo de produção, portanto estão sendo estudadas medidas que diminuam estes gastos visando lucro para o setor. E algumas destas medidas é a utilização de aditivos alternativos, que visam melhorar o aproveitamento de nutrientes das dietas e com isso melhorar o desempenho dos animais.

Barbosa (2009), sugere outro ponto importante para produção avícola que é a busca por produtos que ajudam na integridade da microbiota intestinal, que sem dúvida é a uma das principais responsáveis pelo melhor desempenho do animal. Embasado nisso ingredientes de origem microbiana como probióticos e prebióticos têm merecido atenção como uma alternativa ao uso dos tradicionais antibióticos. Embora haja necessidade de mais pesquisas, a utilização de probióticos e prebióticos representa um avanço tecnológico, aplicando os efeitos benéficos propiciados pela natureza às criações industriais (FURLAN; MACARI; LUQUETTI 2004).

Para obtenção de melhores resultados no desempenho e maximização da produção a partir da década de 50 foram introduzidos antibióticos como promotores de crescimento na alimentação dos animais. Araujo et al. (2007) lembram que além da vacinação, nenhum outro avanço em sanidade foi mais significativo que o desenvolvimento dos antibióticos, pois combatem infecções bacterianas, tendo estes avanços tecnológicos mudado a indústria e proporcionado grande eficiência à produção animal. 
Estes promotores agem no controle da microbiota intestinal combatendo agentes patogênicos ao processo digestivo, os quais deprimem os microorganismos considerados indesejáveis e proporcionam um meio favorável para aqueles considerados desejáveis (FLEMING, 2005).

As grandes demandas da indústria avícola aliada ao curto ciclo de produção das aves, associado à grande produção, foram um dos motivos que os antibióticos passaram a ser usados em doses sub-terapêuticas como promotores de crescimento, tendo o seu uso banido em 2006 pela União Européia, que alegava resistência bacteriana, resíduos na carne, leite e ovos prejudicando assim a saúde humana (TOLEDO et al., 2007; GODOI et al., 2008). Após estas restrições tornou-se cada vez maior a busca por produtos que substituam os antibióticos de forma similar, porém sem causar danos a seres humanos e ao animal. Os prováveis substitutos promotores de crescimento devem manter as ações benéficas dos antibióticos e eliminar as indesejáveis, como a resistência bacteriana (LODDI, 2000).

Muitas organizações têm se manifestado contra o uso de aditivos promotores de crescimento em rações para aves. Órgãos ligados a saúde, ONGs e imprensa estão conseguindo sensibilizar a opinião pública principalmente nos países europeus contra o seu uso e banimento. Assim em muitos países surge a regulamentação dos aditivos alimentares alternativos, tendo controle de dosagem, indicações e produtos específicos (ALBINO et al., 2006).

Segundo Menten (2002) e Langhout (2005) a retirada total dos antibióticos promotores de crescimento acarreta queda na lucratividade para o setor, com diminuição média de desempenho de 3 a 7\%, causando malefícios sobre a saúde animal e a mortalidade; com isso, há uma necessidade de se introduzir estratégias novas a fim de contornar esses efeitos negativos. Atualmente existem muitos aditivos alimentares disponíveis no mercado. Com base em seu mecanismo de ação potencial, os ácidos orgânicos, os óleos essenciais (fitoterápicos) entre outros, podem ser o tipo mais relevante de aditivos para desenvolver uma estratégia de alimentação isenta de antibióticos.

Os aditivos vêm sendo utilizados na produção animal com o objetivo de aumentar as taxas de crescimento e sobrevivência, melhorar a saúde do trato gastrintestinal e a eficiência alimentar, poupar energia e reduzir as cargas patogênicas e a produção de dejetos, minimizando o impacto ambiental pela redução da transmissão de patógenos via alimentos (GODOI et al., 2008). Além de prebióticos e probióticos outros aditivos também vêm sendo utilizados como ácidos orgânicos, óleos essenciais e extratos de plantas como alternativa para esta restrição. 
Os aditivos também são capazes de promover a integridade intestinal, combatendo a colonização de microrganismos patogênicos à microbiota, embora existam vários fatores contribuindo para o desempenho como um todo. Pesquisas têm demonstrado que ácidos orgânicos, enzimas, simbióticos, prebióticos, probióticos e aditivos fitogênicos quando adicionados a ração proporcionaram aos animais desempenho semelhante ou melhor em relação aos promotores de crescimento convencionais.

\subsection{MANANOLIGOSSACARÍDEOS (MOS)}

Os mananoligossacarídeos são considerados prebióticos, denominados ingredientes alimentares não digeríveis na porção proximal do trato gastrintestinal de animais monogástricos, e são responsáveis por estimular o crescimento seletivo de bactérias benéficas como Bifidobaterium e Lactobacillus no intestino, melhorando a microbiota (GIBSON; ROBERFROID, 1995). Neste contexto, (MACARI; FURLAN, 2005) consideram prebióticos, carboidratos não digeríveis como oligossacarídeos, alguns peptídeos e lipídeos não digeríveis. E neste mesmo grupo está incluída a parede celular de plantas e leveduras que possuem em sua constituição glicomananoproteínas em especial mananoligossacarídeos que conseguem ligar-se às fímbrias das bactérias e inibir a colonização no trato gastrintestinal e também ser utilizados como nutrientes pelas bactérias (MAIORAKA et al., 2001). As fímbrias são filamentos protéicos delgados que se projetam da superfície da bactéria e a adesão ocorre quando sítios de ligação em suas extremidades (glicocálix) reagem com receptores específicos situados na superfície das células do hospedeiro (OLIVEIRA et al., 2007; BARBOSA, 2009).

Macari e Maiorka (2000), afirmam que é através do glicocálix que as baterias se fixam ao enterócito da parede intestinal, porém salientam que esta pode não ser a única forma de ação do glicocálix, mas também armazenar e concentrar enzimas digestivas produzidas pelas bactérias, enzimas estas que liberam substratos importantes para a multiplicação do organismo. Esta aderência à mucosa é uma das principais causas da colonização das bactérias patogênicas e os efeitos maléficos causados por elas, e é através da ação dos prebióticos que se tem a anibição da colonização e fixação por parte estes patógenos. Esta ação se baseia em sintetizar compostos que ocupem e bloqueiem o loco ativo de ação da lectina; estabelecer bloqueio dos receptores nas células hospedeiras, entre outros. 
Segundo (LIMA, 2008), alguns resultados defendem a adição de prebióticos na alimentação de frangos de corte pois eles trazem benefícios para o desenvolvimento das vilosidades intestinais e fazem com que a condição de eubiose ocorra, impossibilitando o estabelecimento de Escherichia coli, Clostridium sp, Salmonella sp, e com isso aumentando o número de bactérias benéficas produtoras de ácidos orgânicos, reduzindo o pH no lúmen intestinal.

MOS são obtidos de parede celular de leveduras (Saccharomyces cerevisae), esta parede é constituída de proteínas e carboidratos do qual fazem parte glucose e manose em quantidades semelhantes e também N-acetilglucosamina (FURLAN; MACARI; LUQUETTI, 2004). A parede celular é separada do conteúdo intracelular, e o líquido contendo MOS é evaporado a baixa temperatura (spray dry) para evitar a destruição da parte funcional da molécula de MOS (SPRING, 2000). Na indústria vem sendo utilizados como adsorvente de bactérias patogênicas e aflatoxinas, pois reduz o efeito das micotoxinas. Seu principal modo de ação baseia-se na capacidade de se ligar as fímbrias das bactérias patogênicas impedindo que estas consigam aderir ao epitélio intestinal e, colonizarem o trato gastrointestinal (COLLET, 2003). Estas bactérias gram-negativas ligam-se aos MOS ao invés de ligarem-se as células epiteliais, percorrendo o trato sem colonizá-lo (SANTOS JR; FERKET, 2007), o que faz com que haja remoção de bactérias patogênicas. Com isto reduz lesões intestinais, pois protege a mucosa e proporciona maior altura de vilos e profundidade de cripta.

\section{3 ÁCIDOS ORGÂNICOS}

Os ácidos orgânicos são considerados substâncias que possuem pelo menos uma carboxila em sua estrutura, sendo incluídos os aminoácidos e os ácidos graxos. Quando utilizados na nutrição animal trata-se de ácidos fracos de cadeia curta com fórmula molecular C1-C7 (PENZ; SILVA; RODRIGUES, 1993). A constante de dissociação (Ka) dos ácidos orgânicos, significa a capacidade de doar prótons $\left(\mathrm{H}^{+}\right)$para o meio, isto faz com que eles atuem contra microrganismos. Todo ácido tem sua constante de dissociação pKa, e quanto mais fácil é a doação de hidrogênios para o meios, mais forte é considerado o ácido (FLEMMING, 
2010).Os ácidos orgânicos são cada vez mais utilizados na alimentação de frangos de corte pois possuem efeito antibacteriano semelhante aos antibióticos (DIBNER; BUTTIN, 2002).

Segundo Bellaver e Schuermann (2004) suas funções são variadas e algumas delas não estão relacionadas à nutrição. Eles são capazes de produzir acidez, diminuindo o pH na parte inicial do trato digestivo e assim agir como flavorizantes, retardando a degradação enzimática. Atuam também como agentes quelantes, reduzindo a oxidação da catálise dos metais- íons, atuando na inibição do crescimento microbiano. Esta inibição microbiana se deve ao fato dos ácidos orgânicos diminuírem a capacidade de aderência por parte das bactérias às fímbrias na parede intestinal, função similar aos prebióticos, e atuam ativamente na descamação de proteínas. Possuem capacidade aniônica tamponante com cátions das dietas, aumentando a digestibilidade e retenção desses elementos.

O peso molecular dos ácidos também pode influenciar na sua eficiência, pois ácidos com peso molecular menor como os ácidos fórmico e propiônico, possuem melhor eficiência nutricional do que ácidos com peso molecular maior como os ácidos fumárico e cítrico. (BATISTA, 2005) comenta que bactérias gram- negativas têm maior susceptibilidade aos ácidos orgânicos com menos de 8 carbonos em sua molécula, já as gram positivas aos de maior cadeia carbônica.

Para as aves devem-se tomar alguns cuidados com a adição de ácidos orgânicos na alimentação, pois as aves possuem acidificação natural desde o primeiro dia de idade. Outro cuidado a ser levado em conta é o menor comprimento e tempo de passagem do alimento no trato digestivo, além da grande capacidade secretória de pepsinogênio e ácido clorídrico no proventrículo (KIEN et al., 2000). Além, disto Adams (1999) afirma que são ótimos na preservação de grãos e rações, sanitização da carne além claro de ser usado como promotor de crescimento.

As bactérias são capazes de absorver facilmente os ácidos orgânicos através da sua parede celular. Dentro da célula após sua absorção o ácido é capaz de danificar a estrutura de DNA da célula bacteriana através da sua porção aniônica, impedindo que elas se dividam trazendo a morte da bactéria. A porção catiônica é capaz de reduzir o $\mathrm{pH}$ celular, fazendo a célula bacteriana utilizar energia para liberar prótons, causando exaustão celular (LANGHOUT, 2005).

A adaptação ao meio ácido por parte das bactérias gram- negativas e positivas pode ocorrer devido a longas exposições ao ácido, aumento de $\mathrm{pH}$ do meio e ao estado de anaerobiose (FUKAYAMA, 2005). 
Os efeitos no desempenho dos animais alimentados com ácidos orgânicos dependem não só do seu modo de ação, mas também da idade dos animais, dos ingredientes utilizados na dieta, e da real capacidade desse acidificante reduzir o $\mathrm{pH}$ do trato gastrintestinal.

\subsection{EXTRATOS DE PLANTAS}

Para o controle de diferentes enfermidades nas criações comerciais, novas alternativas vêm sendo utilizadas em virtude do aumento de patógenos resistentes a utilização de antibióticos promotores de crescimento. Uma dessas alternativas é a utilização de extratos vegetais, os quais possuem ação antimicrobiana (BARBOSA, 2009).

A definição de extratos vegetais dada por (FLEMMING, 2010), os definem como uma mistura de metabólitos secundários obtidos da fração volátil das plantas através da destilação por vapor. Eles também podem ser produzidos sinteticamente (ZHANG et al., 2005).

Os extratos vegetais vêm sendo estudados devido seu efeito antimicrobiano, antioxidante e digestivo, tendo lugar de destaque como substituto aos antibióticos melhoradores de desempenho (RIZZO et al., 2010). Estas melhoras são possíveis através da utilização de algumas espécies de plantas como o orégano, a pimenta e o tomilho entre outros.

Os princípios ativos dos extratos vegetais são os responsáveis pelos efeitos positivos, pois os compostos químicos presentes na planta conferem a elas efeitos terapêuticos e a inclusão na alimentação animal acarreta em ausência de toxicidade (KAMEL, 2000). Segundo Lee et al. (2004), estes princípios ativos podem sofrer variações em sua concentração de acordo com a espécie de planta, parte utilizada, solo e condições ambientais, portanto uma mesma planta pode ter mais de um princípio ativo, tendo como exemplo o orégano que possui 30 diferentes compostos químicos antibacterianos.

Os óleos essenciais que são constituintes dos extratos de vegetais possuem em sua constituição substâncias complexas voláteis lipofílicas (SIMÕES; SPITZER, 1999) além de diferentes componentes como hidrocarbonetos terpênicos, alcoóis simples, aldeídos, cetonas, fenóis, ésteres, entre outros. Um composto que tem suas funções famacológicas ativas é considerado marjoritário, o que lhe proporciona características próprias de sabor e odor (SANTURIO et al., 2007).

Além da função antimicrobiana, outros mecanismos de ação dos extratos vegetais são observados, como a palatabilidade e o consumo, influenciando no aumento da salivação, provocam mudanças morfo-histológicas do trato gastrointestinal (JAMROZ et al., 2006), 
estimulando a produção de enzimas digestivas e pancreáticas, tendo assim melhor digestibilidade e absorção de nutrientes (HERNÁNDEZ et al., 2006).

Outros efeitos dos óleos essenciais é que são capazes de agir em microrganismos que emitem fímbrias. Até o momento não existem dados que comprovem o aparecimento de resistência bacteriana ao seu uso. Agem também com eficiência nos estágios iniciais de formação da membrana celular impedindo a multiplicação bacteriana (FLEMMING, 2010). O efeito antifúngico ocorre pela interferência na transferência de elétrons nas células, no metabolismo e divisão celular e na inibição de enzimas de síntese da parede celular. No extrato de pimenta seu principal constituinte é a capsaicina que é responsável pela secreção de sais biliares e estimulam a ação de enzimas digestivas no pâncreas da mucosa intestinal (LEE et al., 2003).

Com a forte pressão por parte da sociedade, contra a utilização de antibióticos sintéticos na alimentação animal, fica cada vez mais forte a procura por alimentos que mantenham ou até mesmo melhorem os índices zootécnicos, reduza os índices sanitários e melhore os econômicos, e é através de pesquisas que se busca a aceitação por parte do mercado consumidor. 


\section{REFERÊNCIAS}

ADAMS, C. A. Nutricines. Food components in Health and Nutrition. Nottingham: Univ. Nottingham, 1999.

ALBINO, L. F. T.; FERES, F. A.; DIONIZIO M. A.; ROSTAGNO, H. S.; VARGAS Jr, J. G.; CARVALHO, D. C. O.; GOMES, P. C.; COSTA, C. H. R. Uso de prebióticos à base de mananoligossacarídeo em rações para frangos de corte. Revista Brasileira de Zootecnia, v. 35, n. 3, p. 742-749, 2006.

ALBUQUERQUE, R. Antimicrobianos como aditivos zootécnicos promotores de crescimento. In: PALERMO NETO, J.; SPINOSA. H. S.; GÓRNIAK, S. L. Farmacologia aplicada à avicultura. São Paulo: Roca, 2005. p. 149-159.

ARAUJO, J. A.; SILVA, J. H. V.; A. L. L.; AMÂNCIO, A. L. L.; LIMA, M. R.; LIMA, C. B. Uso de aditivos na alimentação de aves. Acta Veterinária Brasílica, v. 1, n. 3, p. 69-77, 2007.

VISITE. O portal da avicultura na internet. Campinas, 26 de maio. 2011. Disponível em: $<$ http://www.avisite.com.br/>. Acesso em: 26 de abril 2011.

BARBOSA, N. A. R. Avaliação de aditivos em dietas de frangos de corte. 2009. 166 f. Tese (Doutorado em Zootecnia) - Faculdade de Ciências Agrárias e Veterinárias, Universidade Estadual Paulista, Jaboticabal, 2009.

BATISTA, L. S. Flavonóides e mananoligossacarídeos em dietas para frangos de corte. 2005. 54 f. Dissertação (Mestrado em Zootecnia) - Universidade Estadual Paulista Faculdade de Medicina Veterinária e Zootecnia, Universidade Estadual Paulista, Botucatu, 2005.

BELlAVER, C.; SCHEUERMANN, G.; Aplicações dos ácidos orgânicos na produção de aves de corte. In: PALESTRA APRESENTADA NA CONFERÊNCIA AVISUI, 2004, Florianópolis. 2004, p. 1-16.

COLLET, S. Saúde e imunidade: como obter o equilibrio ideal. Feeding Times, v. 8, n. 2, p. 13-14, 2003.

DIBNER, J. J.; BUTTIN, P. Use of Organic Acids as a Model to Study the Impact of Gut Microflora on Nutrition and Metabolism. Journal of Applied Poultry Reserarch, v. 11, p. 453-463, 2002.

FLEMMING, J. S. Utilização de leveduras, probióticos e mananoligossacarídeos (MOS) na alimentação de frangos de corte. 2005. 109 f. Tese (Doutorado em Tecnologia de Alimentos), Universidade Federal do Paraná, Curitiba, 2005.

FLEMMING, J.S. Promotores de crescimento alternativos: ácidos orgânicos, óleos essenciais e extratos de ervas. Engormix, Chacabuco, 28 jul. 2010. Disponível em: $<$ http://pt.engormix.com/MA-avicultura/nutricao/artigos/promotores-crescimentoalternativos-acidos-t296/p0.htm>.Acesso em: 29 maio 2011. 
FUKAYAMA, E. H.; BERTECHINI, GERALDO, A.; KATO, R. K.; MURGAS, L. D. S. Extrato de Orégano como Aditivo em Rações para Frangos de Corte. Revista Brasileira de Zootecnia, v. 34, n. 6, p. 2316-2326, 2005. Suplemento.

FURLAN, R. L.; MACARI, M.; LUQUETTI, B. C. Como avaliar os efeitos do uso de prebióticos, probióticos e flora de exclusão competitiva. In: SIMPOSIO TÉCNICO DE INCUBAÇÃO, MATRIZES DE CORTE E NUTRICAO, 2004, Balneário Camboriú. Anais... Balneário Camboriú, 2004. p. 6-28.

GIBSON, G. R.; ROBERFROID, M. B. Dietary modulation of the human colonic microbiota: introducing the concept of prebiotics. Journal of Nutrition, v. 125, n. 6, p. 1401-1412, 1995.

GODOI. M. J. S. ; AlBINO, L. F. T. ; H. S. ROSTAGNO. H. S. ; GOMES, P. C. ; BARRETO, S. L. T. ; VARGAS Jr, J. G. Utilização de aditivos em rações formuladas com milho normal e de baixa qualidade para frangos de corte. Revista Brasileira de Zootecnia, v.37. n.6, p.1005-1011, 2008.

HERNÁNDEZ, F.; MADRID, J.; GARCÍA, V.; ORENGO, J.; MEGÍAS, M. D. Influence of two plant extracts on broilers performance, digestibility, and digestive organ size. Poultry Science, v._83, p. 169-174, 2004.

JAMROZ, D.; WERTELECKI, T.; HOUSZKA, M.; KAMEL, C. Influence of diet type on the inclusion of plant origin active substances on morphological and histochemical characteristics of the stomach and jejunum walls in chicken. Journal of Animal Physiology and Animal Nutrition, v.90, p.255-268, 2006.

KAMEL, C. A novel look at a classic approach of plant extracts. The International Journal on Feed, Nutrition and Technology, Doetinchen, v. , n. , p.19-21, 2000.

KIEN, L. K.; CHANG, J. C.; COOPER, J. R. Butyric acid is synthesized by piglets. American Society for Nutritional Sciences, v. 3, p. 234-237, 2000.

LANGHOUT, P. Alternativas ao uso de quimioterápicos na dieta de aves: a visão da indústria e recentes avanços. In: CONFERENCIA APINCO DE CIENCIA E TECNOLOGIA A VíCOLAS, 2005, Santos, SP. Anais... Santos: Apinco, 2005. p. 21-33.

LEE, S. E.; HWANG, H.J.; HA, J.S.; JEONG, H.S.; KIM, J.H. Screening of medicinal plant extracts for antioxidant activity. Life Sciense, v. 73, p. 167-179, 2003.

LEE, K.W.; EVERTS, H.; BEYNEN, A.C. Essential oils in broiler nutrition. International Journal of Poultry Science, v. 12, p. 738-752, 2004.

LIMA, H. J. D. Prebióticos na dieta de frangos de corte. Revista Eletrônica Nutritime, v._5, n. 4, p. 599-606, 2008. Disponível em:

$<\underline{\text { http://www.nutritime.com.br/arquivos internos/artigos/061V5N4P599 } 606 \text { JUL2008_pdf }>}$ .Acesso em: 1 junho 2011. 
LODDI, M. M.; GONZALES, E.; TAKITA, T. S.; MENDES, A. A.; ROÇA, R. O. Uso de Probiótico e Antibiótico sobre o Desempenho, o Rendimento e a Qualidade de Carcaça de Frangos de Corte. Revista Brasileira de Zootecnia, v. 29,n. 4, p. 1124-1131, 2000.

MACARI, M.; FURLAN, R. L. Probióticos. . In: CONFERÊNCIA APINCO DE CIÊNCIA E TECNOLOGIA AVÍCOLAS, 2005, Campinas, SP. Anais... Campinas: FACTA, 2005. v. I, p. 53-71.

MACARI, M.; MAIORKA, A. Função gastrintestinal e seu impacto no rendimento avícola. In: CONFERÊNCIA APINCO DE CIÊNCIA E TECNOLOGIA AVÍCOLAS, 2000, Campinas. Anais... Campinas: FACTA, 2000. v. 2, p. 161-174.

MAIORKA A.; SANTIN, E.; SUGETA, S. M.; ALMEIDA, J. G.; MACARI, M. Utilização de prebiótico, probiótico ou simbiótico em dietas para frangos. Revista Brasileira de Ciência Avícola, v. 3, n. 1, p. 75- 82, 2001.

MENTEN, J. F. M. Próbioticos, prébioticos e aditivos fitogênicos na nutrição de aves. In: SIMPÓSIO SOBRE INGREDIENTES NA ALIMENTAÇÃO ANIMAL, 2002, Campinas. Anais... Campinas: Colégio Brasileiro de nutrição animal, 2002. p. 251-276. 


\section{CAPÍTULO II - UTILIZAÇÃO DE ÁCIDOS ORGÂNICOS, MOS E EXTRATOS DE PLANTAS SOBRE O DESEMPENHO DE FRANGOS DE CORTE}

\section{RESUMO}

Foram utilizados 1140 animais, machos, da linhagem comercial Cobb criados de 1 a 42 dias de idade e alojados em um galpão experimental. Foram testados seis tratamentos, com seis repetições de 40 aves, adotando-se um delineamento experimental inteiramente ao acaso. Os tratamentos foram: T1 - Controle; T2 - Antibiótico (Bacitracina de Zinco); T3 - MOS; T4Ácidos Orgânicos; T5 - MOS + Ácidos Orgânicos, T6- Extratos de Plantas. As variáveis requeridas foram consumo de ração, ganho de peso, conversão alimentar e mortalidade. Os dados foram submetidos à análise de variância e, para a comparação das médias foi utilizado contrastes ortogonais, com um nível de $5 \%$ de probabilidade. Os resultados encontrados mostraram efeito significativo $(\mathrm{p}<0,05)$ para todas as variáveis e todos os períodos estudados, tendo os aditivos alternativos aos antibióticos melhores índices zootécnicos. Isto prova a eficiência da utilização na substituição, não havendo perdas no desempenho.

Palavras- chave: Aditivos. Alta produção. Aves. Carne. 


\begin{abstract}
This study used the 1140 animals, males, the commercial line Cobb raised from 1 to 42 days old and housed in an experimental hall. We tested six treatments with six replicates of 40 birds, adopting a completely randomized experimental design. The treatments were: T1 control, T2 - Antibiotic (Bacitracin Zinc), T3 - MOS-Organic Acids T4, T5 - MOS + Organic Acids, T6-Plant Extract. The required variables were feed intake, weight gain, feed conversion and mortality. Data were subjected to analysis of variance and, for comparison of means was used orthogonal contrasts with a 5\% level of probability. The results showed a significant effect $(\mathrm{p}<0.05)$ for all variables and all time periods, with additives alternative to antibiotics best indexes. This proves use efficiency in replacement with no loss in performance.
\end{abstract}

Key words: Additives. Birds. High production. Meat. 


\section{INTRODUÇÃ̃O}

A indústria avícola passa por uma evolução técnica da qual é possível obter produtos de baixo custo, alta qualidade e comprovada competitividade no mercado avícola mundial (CARRIJO et al., 2005).

No entanto o ambiente em que os animais vivem sofre freqüentes contaminações microbiológicas e este fato pode exercer pressão sobre a saúde e o desempenho dos animais. Quando o ambiente é adequado, com boas maneiras de manejo e sanidade, o efeito da utilização de aditivos promotores de crescimento podem não aparecer sobre o desempenho dos animais (BORATTO et al., 2004).

A busca pelo melhor desenvolvimento e desempenho dos animais em condições cada vez mais intensivas fez com que os aditivos antimicrobianos fossem introduzidos na alimentação de frangos de corte. O uso passou a ser em doses subterapêuticas e isto causou grande pressão para sua proibição. Por este fato os antibióticos promotores de crescimento têm sido banidos da alimentação de aves, e a busca por alternativas naturais para melhorar a produtividade e promover a sanidade animal nos modernos sistemas de produção é um grande desafio. Mananoligossacarídeos, ácidos orgânicos e extratos de vegetais entre outros são alguns destes aditivos alternativos utilizados para este fim.

A grande vantagem desses aditivos alternativos em relação aos antibióticos é a ausência do fenômeno de resistência bacteriana (SANTOS, 2003). O resultado final é o melhor desempenho zootécnico sem aumentar significativamente os custos de produção. 


\section{MATERIAL E MÉTODOS}

\subsection{LOCAL, INSTALAÇÕES E PERÍODO EXPERIMENTAL}

O experimento foi realizado no aviário experimental do Departamento de Nutrição e Produção Animal da Faculdade de Medicina Veterinária e Zootecnia da Universidade de São Paulo, Campus Pirassununga, Estado de São Paulo localizado a $21^{\circ} 8^{\prime \prime}$ de latitude sul e $47^{\circ} 25^{\prime} 42$ " de longitude oeste, a uma altitude de 634 metros, no período de 22 de junho de 2010 a 02 de agosto de 2010 , em um total de 42 dias. O clima da região é subtropical, com inverno seco e verão quente e chuvoso.

Utilizou-se um galpão de alvenaria dividido em 36 boxes de $4,25 \mathrm{~m}^{2}$ cada, sendo a criação das aves feita em piso. Os bebedouros utilizados foram do tipo pendulares e os comedouros tubulares.

As leituras das temperaturas máximas e mínimas foram medidas diariamente por termômetros de bulbo seco localizados em dois pontos distintos do galpão e anotadas. $\mathrm{Na}$ tabela 1, encontram-se as médias das temperaturas nos diferentes períodos experimentais. A mortalidade foi anotada diariamente em uma planilha.

Tabela 1-Médias das temperaturas nos diferentes períodos_experimentais

\begin{tabular}{ccc}
\hline Períodos & T $^{\mathbf{0}}$ C Máx. & T $^{\mathbf{0}} \mathbf{C}$ Mín. \\
\hline 1 à 21 dias de idade & 24,7 & 16,35 \\
22 à 35 dias de idade & 27,28 & 17,07 \\
36 à 42 dias de idade & 25,71 & 14,42 \\
\hline
\end{tabular}




\subsection{ANIMAIS}

Foram utilizados 1440 pintos de um dia de idade, da linhagem comercial Cobb, trazidos do incubatório Globoaves e criados até os 42 dias de idade.

\subsection{DIETA EXPERIMENTAL}

A ração foi diferenciada quanto aos níveis de proteína e energia em três fases de desenvolvimento, para atender as exigências nutricionais de cada intervalo de criação: inicial (1 a 21 dias), crescimento (22 a 35 dias) e final (36 a 42 dias), segundo Rostagno et al. (2005).

\subsection{DELINEAMNETO EXPERIMENTAL E TRATAMENTOS}

As aves foram alojadas de acordo com um delineamento inteiramente casualizado e distribuídos em seis diferentes tratamentos descritos na tabela 2, com seis repetições (boxes) por tratamento com 40 aves cada.

Tabela 2 - Descrição dos tratamentos

\begin{tabular}{|c|c|}
\hline TRATAMENTOS & COMPOSICÃO \\
\hline $\mathrm{T} 1$ & Controle \\
\hline $\mathrm{T} 2$ & Antibiótico (Bacitracina de zinco) \\
\hline $\mathrm{T} 3$ & MOS (Immunowall) \\
\hline $\mathrm{T} 4$ & Ácidos Orgânicos (Premium Sal Ácido 4) \\
\hline T5 & MOS+Ácidos orgânicos \\
\hline T6 & Extratos de Plantas (XTRACT) \\
\hline
\end{tabular}


O grupo controle foi composto apenas da dieta basal sem qualquer aditivo promotor de crescimento.

O tratamento com antibiótico foi suplementado com bacitracina de zinco na dose de $500 \mathrm{~g} / \mathrm{ton}$ de ração.

O grupo tratado com prebiótico (MOS) composto 100\% de parede celular de levedura Saccharomyces cerevisae, rico em mananoligossacarídeos e beta-glucanos, comercializado sob o nome Immunowall pela empresa ICC foi adicionado à dieta na dose de $1 \mathrm{~kg} / \mathrm{ton}$ de ração na forma em pó para todas as fases de criação.

O grupo tratado com a mistura de ácidos orgânicos, comercialmente chamado de Premium Sal. Ácido 4 da empresa Nutriacid, tendo em sua composição ácido benzóico 58\%, ácido fórmico, ácido cítrico, água e silicatos, foi suplementado com 1,5kg/ton de ração em pó nas duas primeiras fases de criação (1à 21 dias e de 22 à 35 dias) e com 1kg/ton de ração na última fase de criação (36 à 42 dias).

O grupo tratado com extratos de plantas comercialmente conhecido por XTRACT da empresa Evonik Degussa que em sua composição apresenta carvacol, cinamaldeído, capsicum oleoresin/ sólido (pó) laranja claro, foi suplementado com 150g/ton de ração no período inicial de criação (1 à 21dias), com $120 \mathrm{~g} /$ ton de ração no período de crescimento (22 à 35 dias) e com $100 \mathrm{~g} /$ ton de ração no período final (36 à 42 dias).

O grupo tratado com a associação do ácido + Mos foi suplementado com $1 \mathrm{~kg} /$ ton de ração de MOS + 1,5kg/ton de ração de ácido nos períodos de (1 à 21 e 22 à 35 dias) e com $1 \mathrm{~kg} /$ ton de ração de MOS + 1kg/ton de ração de ácido no período (36 à 42 dias).

Todos os aditivos foram utilizados de acordo com as recomendações do fabricante e adicionados em substituição ao equivalente em peso de material inerte (caolim), ajustando-se as composições percentuais das diferentes rações experimentais.

Os tratamentos não foram submetidos a qualquer anticoccidiano ou aditivos diferentes dos citados anteriormente.

$\mathrm{Na}$ tabela 3, estão os valores nutricionais dos ingredientes e a composição calculada nos períodos de criação, além das dosagens utilizadas dos diferentes aditivos estudados. 
Tabela 3 - Dietas Experimentais

\begin{tabular}{|c|c|c|c|c|c|c|c|c|c|c|c|c|c|c|c|c|c|c|}
\hline \multicolumn{19}{|c|}{ Tratamentos } \\
\hline \multirow{2}{*}{ Ingredientes (kg) } & \multicolumn{6}{|c|}{1 a 21 dias idade } & \multicolumn{6}{|c|}{22 a 35 dias idade } & \multicolumn{6}{|c|}{36 a 42 dias idade } \\
\hline & CONT. & ANT. & MOS & ÁC. & MOS+ÁC. & EXT. & CONT. & ANT. & MOS & ÁC. & MOS+ÁC. & EXT. & CONT. & ANT. & MOS & ÁC. & MOS+ÁC. & EXT. \\
\hline Milho & 58,71 & 58,71 & 58,71 & 58,71 & 58,71 & 58,71 & 60,7 & 60,7 & 60,7 & 60,7 & 60,7 & 60,7 & 65,05 & 65,05 & 65,05 & 65,05 & 65,05 & 65,05 \\
\hline Farelo de Soja & 34,34 & 34,34 & 34,34 & 34,34 & 34,34 & 34,34 & 31,68 & 31,68 & 31,68 & 31,68 & 31,68 & 31,68 & 27,6 & 27,6 & 27,6 & 27,6 & 27,6 & 27,6 \\
\hline Óleo & 2,659 & 2,659 & 2,659 & 2,659 & 2,659 & 2,659 & 3,67 & 3,67 & 3,67 & 3,67 & 3,67 & 3,67 & 3,601 & 3,601 & 3,601 & 3,601 & 3,601 & 3,601 \\
\hline Fosfato Bicálcico & 1,82 & 1,82 & 1,82 & 1,82 & 1,82 & 1,82 & 1,57 & 1,57 & 1,57 & 1,57 & 1,57 & 1,57 & 1,418 & 1,418 & 1,418 & 1,418 & 1,418 & 1,418 \\
\hline Calcário Calcítico & 0,833 & 0,833 & 0,833 & 0,833 & 0,833 & 0,833 & 0,87 & 0,87 & 0,87 & 0,87 & 0,87 & 0,87 & 0,828 & 0,828 & 0,828 & 0,828 & 0,828 & 0,828 \\
\hline Sal kg & 0,446 & 0,446 & 0,446 & 0,446 & 0,446 & 0,446 & 0,43 & 0,43 & 0,43 & 0,43 & 0,43 & 0,43 & 0,404 & 0,404 & 0,404 & 0,404 & 0,404 & 0,404 \\
\hline Suple. Min./ Vit. ${ }^{1}$ & 0,3 & 0,3 & 0,3 & 0,3 & 0,3 & 0,3 & 0,3 & 0,3 & 0,3 & 0,3 & 0,3 & 0,3 & 0,3 & 0,3 & 0,3 & 0,3 & 0,3 & 0,3 \\
\hline Metionina & 0,274 & 0,274 & 0,274 & 0,274 & 0,274 & 0,274 & 0,25 & 0,25 & 0,25 & 0,25 & 0,25 & 0,25 & 0,245 & 0,245 & 0,245 & 0,245 & 0,245 & 0,245 \\
\hline Lisina & 0,26 & 0,26 & 0,26 & 0,26 & 0,26 & 0,26 & 0,22 & 0,22 & 0,22 & 0,22 & 0,22 & 0,22 & 0,275 & 0,275 & 0,275 & 0,275 & 0,275 & 0,275 \\
\hline Treonina & 0,081 & 0,081 & 0,081 & 0,081 & 0,081 & 0,081 & 0,06 & 0,06 & 0,06 & 0,06 & 0,06 & 0,06 & 0,078 & 0,078 & 0,078 & 0,078 & 0,078 & 0,078 \\
\hline Bacitracina $^{2}$ & - & 0,05 & - & - & - & - & - & 0,05 & - & - & - & - & - & 0,05 & - & - & - & - \\
\hline MOS $^{3}$ & - & - & 0,1 & - & 0,1 & - & - & - & 0,1 & - & 0,1 & - & - & - & 0,1 & - & 0,1 & - \\
\hline Extratos ${ }^{4}$ & - & - & - & - & - & 0,015 & - & - & - & - & - & 0,012 & - & - & - & - & - & 0,01 \\
\hline Ácido ${ }^{5}$ & - & - & - & 0,15 & 0,15 & - & - & - & - & 0,15 & 0,15 & - & - & - & - & 0,1 & 0,1 & - \\
\hline Inerte $^{6}$ & 0,27 & 0,22 & 0,17 & 0,12 & 0,02 & 0,255 & 0,25 & 0,2 & 0,15 & 0,1 & - & 0,238 & 0,2 & 0,15 & 0,1 & 0,1 & - & 0,19 \\
\hline \multicolumn{19}{|c|}{ Composição Calculada } \\
\hline Proteína Bruta (\%) & & & 21,63 & & & & & & 19,73 & & & & & & 18,31 & & & \\
\hline $\begin{array}{l}\text { Energia Met. } \\
(\mathrm{kcal} / \mathrm{kg})\end{array}$ & & & 3.005 & & & & & & 3.150 & & & & & & 3.200 & & & \\
\hline Cálcio $(\%)$ & & & 0,921 & & & & & & 0,837 & & & & & & 0,775 & & & \\
\hline Fósforo Disp. (\%) & & & 0,46 & & & & & & 0,418 & & & & & & 0,386 & & & \\
\hline $\mathrm{Na}(\%)$ & & & 0,221 & & & & & & 0,208 & & & & & & 0,198 & & & \\
\hline Lisina Dig. (\%) & & & 1,276 & & & & & & 1,099 & & & & & & 1,048 & & & \\
\hline $\begin{array}{c}\text { Met + Cist Dig. } \\
(\%)\end{array}$ & & & 0,906 & & & & & & 0,791 & & & & & & 0,755 & & & \\
\hline Treonina Dig.(\%) & & & 0,83 & & & & & & 0,714 & & & & & & 0,681 & & & \\
\hline
\end{tabular}

1-Suplemento Mineral e Vitamínico: Vit. A=11.663.800 U.I.; Vit. D3= 401.700 U.I.; Vit. E= 37.299 U.I.; Vit. K3=283,2 mg; Vit. B1=301,5 mg; Vit. B2=675 mg; Vit B6= 373,5; Niocina= 4,5 g; Ácido pantotênico= 1767 mg; Ácido fólico=148,5 mg; Biotina= 15 mg; Ferro= 7,44 g; Manganês= 9,99 g; Zinco= 7,704; Cobre= 1284 mg; Selênio= $45 \mathrm{mg}$; Iodo= $150 \mathrm{mg} ;$ B.H.T. $=300 \mathrm{mg}$.

2-Bacitracina de zinco; 3-MOS: Mananoligossacarídeo; 4- Extrato de plantas; 5- Ácidos Orgânicos; 6- Caulim. 


\subsection{MANEJO DAS AVES}

O manuseio dos pintinhos foi cuidadoso, liberando-os junto às fontes de aquecimento, bebedouro e comedouro. Aquecedores (campânulas) foram ligados antes da chegada das aves para estabilizar a temperatura, aquecer a cama onde as aves permaneceram durante toda a criação. O manejo das cortinas foi feita para uma boa ventilação e iluminação do galpão, bem como a limpeza e nível adequado de água e ração nos bebedouros e comedouros. A limpeza dos bebedouros não foi feita diariamente, tendo dias intercalados para que o desafio fosse aumentado.

A ração foi fornecida ad libitum nos comedouros tipo tubular. A cama era reutilizada e de casca de arroz, com o intuito de aumentar o desafio sanitário.

As aves foram pesadas no primeiro dia do experimento e ao final de cada período de criação (aos 21, 35 e aos 42 dias de idade). Todas as aves foram vacinadas no galpão e individualmente, contra a doença de Newcastle via ocular.

\subsection{PARÂMETROS AVALIADOS}

A pesagem dos animais foi feita no final de cada período. A fim de determinar as variáveis de desempenho nos intervalos: 01-21; 22-35; 36-42 e 01-42 dias. As variáveis mensuradas em cada box foram: ganho de peso (GP), consumo de ração (CR), conversão alimentar (CA), mortalidade (M).

O ganho de peso (g) de cada repetição foi analisado após as pesagens, pela diferença entre o peso final e o peso inicial de cada box.

A quantidade de ração consumida foi calculada pela diferença entre o peso da ração fornecida durante o respectivo período e o peso da sobra ao final desde mesmo período, e dividido pelo número de aves do box.

A conversão alimentar (g/g) foi analisada comparando o ganho de peso e consumo de ração dos animais nos diferentes tipos de tratamentos.

A mortalidade (\%) foi calculada pela relação entre o número de aves que morreram durante o experimento e o número inicial de aves, multiplicada por cem. 


\subsection{ANÁLISE ESTATÍSTICA}

Os resultados foram analisados através do programa computacional Statistical Analysis System (SAS, 9.1.3, 2004), onde a normalidade dos resíduos foi verificada pelo teste de Shapiro- Wilk, e as variâncias pegando-se o maior valor e dividindo pelo menor, tendo o resultado que ser abaixo de 5\%. A análise de variância que separou apenas como causa de variação o efeito de tratamento por se tratar de um delineamento inteiramente casualizado, utilizando-se o procedimento Proc Mixed (Modelos Mistos do SAS), e para o efeito aleatório foi considerado animal dentro de cada box. Para a mortalidade os dados foram transformados para raiz de $(x+0,5)^{1 / 2}$, sendo $\mathrm{x}$ a porcentagem da mortalidade.

Para a comparação das médias foi utilizada a metodologia dos contrastes ortogonais, apresentados na tabela 4 .

Tabela 4 - Esquema de contrastes dos efeitos entre os tratamentos

\begin{tabular}{lccccccc}
\hline \multicolumn{1}{c}{ Contrastes } & \multicolumn{7}{c}{ Efeitos } \\
C1= Controle vs Aditivos & 4 & 0 & -1 & -1 & -1 & -1 \\
C2= Antibiótico vs Aditivos & 0 & 4 & -1 & -1 & -1 & -1 \\
C3= Extrato vs Aditivos & 0 & 0 & -1 & -1 & -1 & 3 \\
C4= MOS vs MOS+Ácidos & 0 & 0 & -1 & 0 & 1 & 0 \\
C5= Ácidos vs MOS+Ácidos & 0 & 0 & 0 & -1 & 1 & 0 \\
\hline
\end{tabular}




\section{RESULTADOS E DISCUSSÃO}

Os resultados de desempenho zootécnico de frangos de corte alimentados com diferentes aditivos no período de (1 a 21 dias, 22 a 35 dias, 36 a 42 dias e 1 a 42 dias) de idade e as análises dos contrastes estão apresentados na tabela 5 .

Através dos contrastes foi possível observar que os tratamentos que tinham algum tipo de aditivo obtiveram melhores índices zootécnicos para todas as variáveis estudadas. 
Tabela 5 - Médias dos tratamentos para consumo de ração (CR), ganho de peso das aves (GP), conversão alimentar (CA), mortalidade (M) e os contrastes e níveis de significância para cada variável nos períodos de 1 a 21,22 a 35, 36 a 42 e 1 a 42 dias de idade

\begin{tabular}{|c|c|c|c|c|c|c|c|c|c|c|c|c|}
\hline \multirow{2}{*}{ Parâmetros } & \multicolumn{7}{|c|}{ Tratamentos } & \multicolumn{5}{|c|}{ Probabilidades $^{1}$} \\
\hline & CRONTROLE & ANTIBIÓTICO & MOS & ÁC. ORG. & MÓS+ÁC. ORG. & EXT. PLANTA & $\mathrm{CV}(\%)$ & $\mathrm{C} 1$ & $\mathrm{C} 2$ & $\mathrm{C} 3$ & $\mathrm{C} 4$ & $\mathrm{C} 5$ \\
\hline \multicolumn{13}{|l|}{ Fase (1-21) } \\
\hline CR $(g)$ & 1145.78 & 1114.29 & 1092.60 & 1093.60 & 1089.02 & 1095.39 & 2.55 & $<0.0001$ & 0.0356 & 0.7202 & 0.7737 & 0.7136 \\
\hline GP $(g)$ & 702.58 & 717.79 & 756.82 & 784.27 & 763.27 & 763.24 & 5.77 & 0.0004 & 0.0048 & 0.7687 & 0.7507 & 0.3060 \\
\hline $\mathrm{CA}$ & 1.62 & 1.54 & 1.43 & 1.39 & 1.42 & 1.43 & 6.68 & $<0.0001$ & 0.0001 & 0.6638 & 0.6286 & 0.4992 \\
\hline $\mathrm{M}(\%)$ & 0.95 & 0.95 & 0.75 & 1.16 & 0.91 & 2.29 & 123.45 & 0.6183 & 0.6183 & 0.0522 & 0.8385 & 0.7600 \\
\hline \multicolumn{13}{|l|}{ Fase (22-35) } \\
\hline CR (g) & 2261.27 & 2062.89 & 2122.13 & 2085.82 & 2100.78 & 2082.83 & 4.72 & 0.0001 & 0.3355 & 0.6153 & 0.6507 & 0.7508 \\
\hline GP $(g)$ & 1256.94 & 1290.95 & 1407.94 & 1396.49 & 1337.98 & 1384.05 & 5.82 & 0.0001 & 0.0027 & 0.9142 & 0.0591 & 0.1101 \\
\hline $\mathrm{CA}$ & 1.80 & 1.60 & 1.51 & 1.49 & 1.57 & 1.50 & 8.66 & $<0.0001$ & 0.0722 & 0.6872 & 0.2497 & 0.1648 \\
\hline $\mathrm{M}(\%)$ & 1.24 & 2.40 & 0.25 & 1.03 & 0.25 & 1.45 & 133.16 & 0.4150 & 0.0104 & 0.1432 & 0.9913 & 0.3116 \\
\hline \multicolumn{13}{|l|}{ Fase (36-42) } \\
\hline CR (g) & 1319.46 & 1297.54 & 1340.23 & 1274.28 & 1304.49 & 1316.46 & 6.43 & 0.7627 & 0.7470 & 0.6153 & 0.6507 & 0.7508 \\
\hline GP $(g)$ & 604.24 & 623.57 & 704.65 & 734.08 & 714.89 & 725.22 & 9.62 & $<0.0001$ & $<0.0001$ & 0.9142 & 0.0591 & 0.1101 \\
\hline $\mathrm{CA}$ & 2.18 & 2.08 & 1.88 & 1.74 & 1.82 & 1.80 & 11.47 & $<0.0001$ & 0.0016 & 0.6872 & 0.2497 & 0.1648 \\
\hline $\mathrm{M}(\%)$ & 0.73 & 0.26 & 0.81 & 0.27 & 0.50 & 0.24 & 227.98 & 0.5831 & 0.7016 & 0.1432 & 0.9913 & 0.3116 \\
\hline \multicolumn{13}{|l|}{ Fase (1-42) } \\
\hline CR (g) & 4747.69 & 4618.75 & 4385.12 & 4298.46 & 4348.34 & 4264.99 & 5.19 & $<0.0001$ & 0.0003 & 0.3071 & 0.6842 & 0.5817 \\
\hline GP (g) & 2573.47 & 2647.48 & 2911.01 & 2890.44 & 2830.43 & 2886.59 & 5.54 & $<0.0001$ & $<0.0001$ & 0.8259 & 0.1168 & 0.2369 \\
\hline $\mathrm{CA}$ & 1.85 & 1.74 & 1.50 & 1.49 & 1.53 & 1.47 & 10.12 & $<0.0001$ & $<0.0001$ & 0.3997 & 0.4632 & 0.3246 \\
\hline $\mathrm{M}(\%)$ & 2.91 & 3.12 & 1.37 & 2.33 & 1.62 & 2.54 & 80.76 & 0.2506 & 0.1638 & 0.3675 & 0.8083 & 0.4936 \\
\hline
\end{tabular}

C.V.- Coeficiente de variação

1- $\mathrm{C} 1=$ controle vs aditivos; $\mathrm{C} 2=$ antibiótico vs aditivos; $\mathrm{C} 3=$ extratos de plantas vs aditivos; $\mathrm{C} 4=$ MOS vs MOS+ ácidos orgânicos; $\mathrm{C} 5=$ ácidos orgânicos vs MOS+ ácidos orgânicos 
O contraste 1 apresentou diferença significativa $(\mathrm{p}<0,05)$, para o consumo de ração,ganho de peso e conversão alimentar de (1 a 21 dias) de idade, tendo o tratamento controle consumido mais ração, menor ganho de peso e maior conversão alimentar em comparação aos diferentes aditivos neste período. Cave (1982), concorda com os resultados encontrados, adicionando ácido propiônico e acético reduziu- se o consumo de ração pelas aves.

Segundo Viola e Vieira (2007), os antibióticos promotores de crescimento têm um papel importante na dieta, pois estão associados à redução na carga microbiana e melhora na microbiota intestinal, porém neste estudo o promotor de crescimento não obteve bons resultados frente aos diferentes aditivos.

A adição de aditivos nas primeiras semanas de vida da ave provavelmente acarretara em resultados mais satisfatórios, pois, sabe-se que as primeiras semanas de vida do animal são fundamentais para o desenvolvimento do trato digestório, tendo a adição desses aditivos e/ou alimentos importância fundamental na manutenção da integridade e desenvolvimento da mucosa intestinal, isto pode ser um dos motivos para a conversão alimentar com $0,5 \%$ de ácido fumárico ter tido pior resultado frente aos demais tratamentos, pois foram adicionados a partir dos 28 dias de idade (CAMPOS et al., 2004).

Godoi et al. (2008) trabalhando com antibiótico (avilamicina) e MOS em diferentes níveis observaram que as aves que não receberam nenhum tipo de aditivo tiveram menor ganho de peso que os demais, e as aves tratadas com diferentes aditivos não tiveram diferença entre si, o mesmo acontecendo com a conversão alimentar e o consumo de ração que não diferiram significativamente. O mesmo aconteceu com Loddi et al. (2000) que não notaram efeito para estes parâmetros.

As variáveis CR, GP e CA no contraste 2 apresentaram diferença significativa $(\mathrm{p}<0,05)$, onde o tratamento com antibiótico obteve maior consumo de ração, menor ganho de peso e conversão alimentar mais elevada em relação aos diferentes aditivos utilizados. Neste mesmo período de vida das aves Batista (2005), utilizando antibiótico, Mos e flavonóides não encontrou efeito significativo entre os tratamentos estudados.

Silva et al. (2009) utilizando prebiótico em frangos de corte discordam dos resultados encontramos neste trabalho, pois não obtiveram diferença significativa em relação ao $\mathrm{CR}, \mathrm{GP}$ e CA, porém encontraram melhor viabilidade de criação \% no tratamento com prebiótico em relação ao sem.

No período de 22 a 25 dias de idade o controle negativo apresentou maior consumo de ração, menor ganho de peso e com isso influenciou também a conversão alimentar que foi pior em relação aos diferentes aditivos utilizados. No mesmo período a utilização de 
antibiótico teve menor ganho de peso em relação aos outros aditivos e também apresentou maior mortalidade em relação aos mesmos, tendo efeito significativo $(\mathrm{p}<0,05)$.

Entre os aditivos utilizados estão uma mistura de ácidos orgânicos (ác. bezóico, ác. fórmico e ác. cítrico) que foram capazes de substituir a utilização do antibiótico (bacitracina de zinco) apresentando melhores resultados de desempenho em todas as variáveis analisadas, isto pode ser atribuído a melhora na capacidade que os ácidos possuem de inibir a proliferação bacteriana, inibindo o pH do trato gastrointestinal. Entretanto Ricke, (2003), afirma que há necessidade de entendimento do modo de ação e a capacidade dos ácidos atuarem sobre os diferentes patógenos.

Maiorka et al. (2004) conduziram dois experimentos utilizando misturas de ácidos orgânicos. No primeiro os tratamentos eram com ou sem mistura de ácidos orgânicos e não foram observadas diferenças significativas aos 7 dias de idade para ganho de peso e consumo de ração, porém para a variável conversão alimentar houve diferença entre os tratamentos, tendo a mistura de ácidos melhor conversão alimentar. Aos 21 dias de idade não houve diferença para nenhum dos parâmetros avaliados. No segundo experimento os tratamentos utilizados foram: com promotor de crescimento; sem promotor e com a mistura de ácidos orgânicos; e com promotor + mistura de ácidos orgânicos, onde os dois últimos obtiveram melhor conversão alimentar com 10,5\% de superioridade em relação aos tratados somente com o promotor, entretanto relata que são necessários mais estudos para que se possam utiliza-los em escala industrial. Contudo, Garcia et al. (2000) obtiveram um aumento de 2,1\% no ganho de peso de 1 a 21 dias de idade, adicionando 0,1\% de uma combinação de ácidos orgânicos. A dosagem do acidificante pode influenciar a falta de resposta na fase final, pois ela é responsável pela constante de dissociação capaz de atuar como acidificante (SCAPINELLO et al., 2001).

Nos períodos de 12 a 21 e 1 a 21 dias de idade, Boratto et al. (2004), encontraram efeito para ganho de peso nos tratamentos com probiótico e antibiótico em relação ao controle e o homeopatia, porém nos demais períodos não obteve efeito , eles afirmam ser difícil comparar estudos com aditivos, pois cada trabalho utiliza um tipo de promotor com diferentes dosagens e formas de administração e também condições experimentais distintas.

No período de 36 a 42 dias de idade o grupo controle teve maior consumo de ração, menor ganho de peso das aves e pior conversão alimentar em relação aos diferentes aditivos, tendo efeito significativo $(\mathrm{p}<0,05)$ durante o período. Já o tratamento com utilização de antibiótico não diferiu significativamente $(p>0,05)$ em relação ao consumo de ração, porém teve menor ganho de peso e com isso refletindo em uma maior conversão alimentar, ou seja, os animais 
consumiram a mesma quantidade de ração dos tratados com diferentes aditivos, porém conseguiram menor peso final no período.

A melhora no desempenho de aves alimentadas com diferentes aditivos vem sendo relatada por vários autores (MAIORKA et al., 2004; GARCIÁ, 2007; VIOLA; VIEIRA, 2007) entretanto essa melhoria não é apenas promovida pelo melhor aproveitamento dos nutrientes, mas também pelo equilíbrio da microbiota bacteriana intestinal das aves.

Observando o período total de criação, foi possível notar diferenças significativas $(\mathrm{p}<0,05)$ em relação ás variáveis ganho de peso, consumo de ração e conversão alimentar. Onde o grupo controle e o grupo com antibiótico obtiveram maior consumo de ração, menor ganho de peso e maior conversão alimentar em relação aos demais aditivos utilizados. O controle negativo teve um ganho de peso 10,64 \% inferior aos demais aditivos, consumindo 8, $92 \%$ a mais de ração com isso obtendo a conversão alimentar 19, 46 \% superior. Já o grupo alimentado com antibiótico também apresentou diferenças bem significativas, porém menores, onde obtiveram ganho de peso $8,66 \%$ menor que os diferentes aditivos, consumiram 6, 38\% a mais de ração tendo a conversão alimentar aumentada em 14,37\%.

Aos 49 dias de idade Skinner et al. (1991), puderam observar que utilizando níveis de ácido fumárico, não obtiveram efeito significativo para 0,5\% de ácido em machos, já em fêmeas a adição de $0,125 \%$ de ácido ocasionou melhor ganho de peso, para consumo de ração a adição de $0,125 \%$ e $0,5 \%$ diferiram do tratamento controle.

No estudo os aditivos conseguiram substituir o promotor de crescimento com sucesso, porém entre os diferentes aditivos não foram encontradas diferenças significativas ( $>>0,05)$, nem em cada período e nem no período total. Talvez os desafios sanitários utilizados não tenham sido suficientes para um único aditivo se destacar frente aos demais. Segundo Rocha (2010), trabalhando com antibiótico, prebiótico, ácidos orgânicos e a mistura deles, notou que as aves que receberam a dieta com prebiótico + ácidos orgânicos obtiveram melhor conversão alimentar em relação as que receberam somente prébiótico, diferentemente do presente estudo que não obteve diferença entre a mistura de aditivos e os demais.

Salazar (2006), obteve efeito significativo utilizando ácido butírico, lático e antibiótico em suas dietas para o parâmetro ganho médio de peso na fase inicial e no período total de criação. Para consumo de ração de ração a interação entre os ácidos teve efeito significativo sendo superior ao grupo controle, porém não diferiu do tratamento com antibiótico em todas as fases estudadas. Viola e Vieira (2007), avaliando o uso de antibióticos e acidificantes na dieta de frangos de corte, notaram que o ganho de peso corporal, e mortalidade não apresentaram diferença significativa no período de 1 a 35 dias de idade, mas foram observadas diferenças 
para conversão alimentar em todos os período estudado, já o consumo de ração não foi afetado pelos diferentes tratamentos, denotando melhora na utilização de nutrientes a partir de uma mesma quantidade de alimento consumida. A explicação dada por eles é que os desafios microbiológicos tenham sido diminuídos com a adição dos acidificantes, porém existam outros benefícios em nível nutricional, celular intestinal ou enzimático que devem ser levados em consideração.

Os resultados positivos observados com a adição de MOS em dietas para frangos de corte podem estar relacionados entre outros fatores, à sua possível melhora na microbiota intestinal, traduzida pelo maior ganho de peso dos animais.

Barbosa (2009), em seu estudo trabalhou com tratamentos contendo antibiótico, MOS em diferentes concentrações e dieta controle, onde no período total de criação observou efeito significativo, ou seja, melhor peso médio das aves, melhor ganho de peso e melhor conversão alimentar nos animais alimentados com MOS, e esta melhora pode ser justificada pela possível redução do $\mathrm{pH}$ intestinal, fazendo com que haja a inibição de microrganismos patogênicos, favorecendo a microbiota benéfica, com provável melhora na integridade da mucosa, melhora no aproveitamento de nutrientes das dietas e com isso melhora no desempenho.

Quando não se tem efeito em nenhuma das variáveis utilizando diferentes aditivos pode-se atribuir as boas condições de manejo, à qualidade das rações utilizadas, em conjunto a provável falta de desafios sanitários. Talvez por alguns destes motivos, Nunes (2008), não encontrou efeito quaisquer dos aditivos em relação ao consumo de ração, trabalhando com antibiótico, prebiótico e probiótico para frangos de corte, em relação a conversão alimentar os aditivos obtiveram resultados semelhantes ao antibiótico, porém não diferiram do grupo controle no período total estudado.

O uso de prebióticos vem sendo muito utilizados para substituição de antibióticos, porém Barbosa (2009) relata que ainda existem muitas contradições no que diz respeito ao seu potencial de ação, por isso é importante tomar os devidos cuidados experimentais para o comportamento dos dados para a detecção de efeitos significativos.

Maiorka et al. (2001), trabalhando com prebiótico, probiótico e simbiótico constataram que as aves que não receberam nenhum tipo de aditivo obtiveram a pior conversão alimentar na fase final de criação, eles atribuem isto ao possível aumento do desafio pois a contaminação da cama aumenta frente a sua saturação, assim a utilização de promotores e aditivos agem reduzindo o número de bactérias patogênicas no lúmen. Outra característica marcante dos prebióticos em especial o MOS é que eles agem bloqueando os sítios de ligação de bactérias 
patogênicas na mucosa intestinal, fazendo com que haja diminuição nos danos, diminuindo o turnover dessas células, tendo assim melhora na absorção de nutrientes (SPRING et al., 2000).

Garciá (2007), utilizando antibiótico, ácido fórmico em diferentes concentrações e extratos de plantas a base de orégano, canela e pimenta encontrou efeito significativo para ganho de peso, onde os animais alimentados com extratos de plantas tiveram menor ganho de peso.

Os óleos essenciais vêm sendo utilizados na alimentação de frangos de corte e começa a atingir parte da indústria avícola por tratar de um produto natural e de origem vegetal. São capazes de combater patógenos e atuar contra fatores estressantes como mudanças de temperatura, luz ou deficiências nutricionais.

Traesel (2009) estudando o efeito de diversos óleos essenciais no desempenho das aves, e observou que animais alimentados com 100ppm de óleo essencial obtiveram resultados semelhantes aos animais alimentados com antibiótico em relação ao peso corporal, quanto ao consumo de alimento não houve efeito significativo entre os tratamentos. $\mathrm{O}$ mesmo ocorreu com Fukayama et al. (2005), que considerando o período de 1 a 21 dias e o período total de criação observaram que não houveram diferenças significativas entre os tratamentos em relação ao consumo de ração, ganho de peso e conversão alimentar, onde o tratamento com extrato de orégano obteve o mesmo desempenho que o antibiótico e também o mesmo que o tratamento controle, estes resultados foram justificados pelo alto desempenho das aves, acima do indicado pelo manual de criação, assim não tendo os benefícios esperados pelos promotores pois as condições de manejo, ambiente e nutrição foram adequadas para que as aves expressassem seu potencial.

Discordando dos resultados encontrados no estudo, Toledo et al. (2007), afim de avaliarem os efeitos da utilização de antibiótico e fitoterápico, isolados ou associados sobre o desempenho de frangos de corte, puderam observar que não houveram efeitos significativos sobre o consumo de ração, ganho de peso e conversão alimentar em nenhuma das fases avaliadas e este resultado foi justificado pela talvez falta de desafios sanitários. 


\section{CONCLUSÃO}

Os aditivos alternativos conseguiram substituir o uso do antibiótico, apresentando índices zootécnicos superiores em todas as fases de criação, podendo ser utilizados sobre o desempenho dos animais, sem perdas econômicas. 


\section{REFERÊNCIAS}

BARBOSA, N. A. R. Avaliação de aditivos em dietas de frangos de corte. 2009. $166 \mathrm{f}$. Tese (Doutorado em Zootecnia) - Faculdade de Ciências Agrárias e Veterinárias, Universidade Estadual Paulista, Jaboticabal, 2009.

BATISTA, L. S. Flavonóides e mananoligossacarídeos em dietas para frangos de corte. 2005. 54 f. Dissertação (Mestrado em Zootecnia) - Faculdade de Medicina Veterinária e Zootecnia, Universidade Estadual Paulista, Botucatu, 2005.

BORATTO, A. J.; LOPES, D. C.; OLIVEIRA, R. F. M.; ALBINO, L. F. T.; MORAES SÁ, L.; OLIVEIRA, G. A. Uso de Antibiótico, de Probiótico e de Homeopatia, em Frangos de Corte Criados em Ambiente de Conforto, Inoculados ou não com Escherichia coli. Revista Brasileira de Zootecnia, v. 33, n. 6, p. 1477-1485, 2004.

CAMPOS, M. P. A.; RABELLO, C. B. V.; SAKOMURA, N. K.; LONGO, F. A.; KUANA, S.: GUT, F. Utilização do ácido fumárico em dietas de frangos de cortecom baixa energia metabolizável. Acta Scientiarum. Animal Sciences, Maringá, v. 26, n. 1, p. 35-39, 2004.

CARRIJO, A. S.; MADEIRA, L. A.; SARTORI, J. R.-; PEZZATO, A.C. ; GONÇALVES, J.C.; CRUZ, V. C.; KUIBIDA, K. V.; PINHEIRO, D. F. Alho em pó na alimentação

alternativa de frangos de corte. Pesquisa Agropecuária Brasileira, Brasília, v. 40, n. 7, p. 673-679, 2005.

CAVE, N. A. G. Effect of dietary short and medium-chain fatty acids on feed intake by chicks. Poultry Science, v. 61, p. 1147-1153, 1982.

FUKAYAMA, E. H.; BERTECHINI, A. G.; GERALDO, A.; KATO. R. K.; MURGAS, L. D. S. Extrato de Orégano como Aditivo em Rações para Frangos de Corte. Revista Brasileira de Zootecnia, v. 34, n. 6, p. 2316-2326, 2005. Suplemento.

GARCIA, R. G.; ARIKI, J.; MORAES, V. M. B.; KRONKA, S. N.; BORGES, S. A, MURATA, L. S. e CAMPOS, V. A. Ação isolada ou combinada de ácidos orgânicos e promotor de crescimento em rações de frango de corte. Revista Brasileira de Ciências Avícola, v. 2, n. 2, p. 149-154, 2000.

GARCI'A, V.; CATALA 'GREGORI, P.; HERNA'NDEZ, F.; MEGI'AS, M. D.: MADRID, J. Effect of Formic Acid and Plant Extracts on Growth, Nutrient Digestibility, Intestine Mucosa Morphology, and Meat Yield of Broilers. Journal Applied Poulttry Reserarch, v. 16, p. 555-562, 2007.

GODOI, M. J. S.; ALBINO, L. F. T.: ROSTAGNO, H. S.; GOMES, P. C.; BARRETO, S. L. T.: VARGAS JR, J. G. Utilização de aditivos em rações formuladas com milho normal e de baixa qualidade para frangos de corte. Revista Brasileira de Zootecnia. v. 37, n. 6, p. 10051011, 2008. 
LODDI, M. M.; GONZALES, E.; TAKITA, T. S.; MENDES, A. A.; ROÇA, R. O. Uso de Probiótico e Antibiótico sobre o Desempenho, o Rendimento e a Qualidade de Carcaça de Frangos de Corte. Revista Brasileira de Zootecnia, v. 29, n. 4, p. 1124-1131, 2000.

MAIORKA. A.; SANTIN, E.; SUGETA. S. M.; ALMEIDA, J. G.; MACARI, M. Utilização de prebiótico, probiótico ou simbiótico em dietas para frangos. Revista Brasileira de Ciência Avícola, v. 3, n. 1, p. 75- 82, 2001.

MAIORKA, A.; SANTIN, A. M. E.; BORGES, S. A.; OPALINSKI, M.; SILVA, A.V. F. Emprego de uma mistura de ácidos fumárico, lático, cítrico e ascorbico em dietas iniciais de frangos de corte. Archives of Veterinary Science, v. 9, n. 1, p. 31-37, 2004.

NUNES, A. D. Influência do uso de aditivos alternativos a antimicrobianos sobre o desempenho, morfologia intestinal e imunidade de frangos de corte. $2008.111 \mathrm{f}$. Dissertação (Mestrado em Medicina Veterinária) - Faculdade Medicina Veterinária e Zootecnia, Universidade de São Paulo, Pirassununga, 2008.

RICKE.S.C. Perspectives on the use of organic acids and short chain fatty acids as antimicrobials. Poultry Science, Savoy, v.82, p.632-639, 2003.

ROCHA, A. P.; ABREU, R. D.; COSTA, M. C. M. M.; OlIVEIRA, G. J. C.; AlBINATI, R. C. B.; PAZ, A. S.; QUEIROZ, L. G.; PEDREIRA, T. M. Prebióticos, ácidos orgânicos e probióticos em rações para frangos de corte. Revista Brasileira Saúde Produção Animal, v. 11, n. 3, p. 793-801, 2010.

ROSTAGNO, H. S. Tabelas Brasileiras para Aves e Suínos. Composição de Alimentos e exigências nutricionais. 2. ed. Viçosa, MG: UFV, 2005. 186 p.

SALAZAR, P. C. R. Efeito dos ácidos lático e butírico, isolados e associados, sobre o desempenho, imunidade humoral e morfometria intestinal em frangos de corte. 2006. 72 f. Dissertação (Mestrado em Medicina Veterinária) - Faculdade Medicina Veterinária e Zootecnia, Universidade de São Paulo, Pirassununga, 2006.

SAS INSTITUTE. SAS/STAT: User's guide. Version 9.1.3 ed. Cary: NC. 2004.

SANTOS, E. C. Aditivos alternativos ao uso de antibiótico na alimentação de frangos de corte. 2003. 226 f. Tese (Doutorado em Zootecnia) - Faculdade Federal de Lavras, Universidade Federal de Lavras, Lavras, 2003.

SCAPINELLO, C.; FARIA, H. G.; FURLAN, A. C.; MICHELAN, A. C; SANTOLIN, M. L. R. Efeito do uso de oligossacarídeo manose e acidificantes em rações com alto teor de amido, pra coelhos em crescimento. Acta Scientiarium, v. 23, n. 4, p. 1039-1043, 2001.

SILVA, V. K.; SILVA, J. D. T.; GRAVENA, R. A.; MARQUES, R. H.; HADA, F. H. A.; MORAES, V. M. B. Desempenho de frangos de corte de 1 a 21 dias de idade alimentados com rações contendo extrato de leveduras e prebiótico e criados em diferentes temperaturas. Revista Brasileira de Zootecnia, v. 38, n. 4, p. 690-696. 2009. 
SKINNER, J. T.; IZAT, A. L.; WALDROUP, P. W. Fumaric Acid Enhances Performance of Broiler Chickens. Poultry Science,v. 70, p. 1444-1447, 1991.

SPRING, P.; WENK, C.; DAWSON, A.; NEWMAN, K. E., The effects of dietary mannanoligosaccharides on cecal parameters and the concentrations of enteric bacteria in ceca of salmonella-challenged broiler chicks. Poultry Science, v. 79, p. 205- 211, 2000.

TOLEDO, G. I. S. P.; COSTA, P. T. C.; SILVA, L. P.; PINTO, D.; FERREIRA, P.; POLETTO, C. J. Desempenho de frangos de corte alimentados com dietas contendo antibiótico e/ou fitoterápico como promotores, adicionados isoladamente ou associados. Ciência Rural, Santa Maria, v. 37, n. 6, p. 1760-1764, 2007.

TRAESEL, C. K. Perfil bioquímico sérico de frangos de corte alimentados com dieta suplementada com óleos essenciais e pimenta. 2009. 55 f. Dissertação (Mestrado em Medicina Veterinária), Faculdade de Medicina Veterinária, Universidade Federal de Santa Maria, Santa Maria, 2009.

VIOLA, E. S.; VIEIRA, S. L. Suplementação de acidificantes orgânicos e inorgânicos em dietas para frangos de corte: desempenho zootécnico e morfologia intestinal. Revista Brasileira de Zootecnia, v. 36, n. 4, p. 1097-1104, 2007. Suplemento. 


\section{CAPÍTUlO III - UTILIZAÇÃO DE ÁCIDOS ORGÂNICOS, MOS E EXTRATOS DE PLANTAS SOBRE A MORFOMETRIA INTESTINAL DE FRANGOS DE CORTE}

\section{RESUMO}

Utilizou-se seis diferentes tratamentos, com seis repetições de 40 aves, adotando-se um delineamento experimental inteiramente ao acaso. Os tratamentos foram: T1 - Controle; T2 Antibiótico (Bacitracina de Zinco); T3 - MOS; T4- Ácidos Orgânicos; T5 - MOS + Ácidos Orgânicos, T6- Extratos de Plantas. Para morfometria intestinal foram utilizados 108 pintos de 1 a 42 dias de idade, da linhagem comercial Cobb, abatidos por deslocamento cervical ao final de cada período (21, 35 e 42 dias de idade). Foram coletados segmentos do intestino delgado, fixados e depois desidratados, diafanizados e corados para posterior leitura. Foram mensuradas medidas dos segmentos intestinais duodeno, jejuno e íleo. Para a análise estatística foi utilizado o método dos contrastes ortogonais onde houve diferenças significativas $(\mathrm{p}<0,05)$ em todos os períodos analisados e também nos diferentes segmentos intestinais e característica desejadas (altura de vilos e profundidade de cripta).

Palavras-chave: Alimentação. Consumo de ração. Conversão alimentar. Ganho de peso. Nutrição. 


\begin{abstract}
With this study used six different treatments with six replicates of 40 birds adopting a completely randomized experimental design. The Treatments were: T1 - control, T2 Antibiotic (Bacitracin Zinc), T3 - MOS-Organic Acids T4, T5 - MOS + Organic Acids, T6Plant Extract. Intestinal morphology were used for 108 chicks 1-42 days old, the commercial line Cobb, killed by cervical dislocation at the end of each period (21, 35 and 42 days age) were collected segments of the small intestine, and then fixed dehydrated and stained for further reading. Were measured size of the segments intestinal duodenum, jejunum and ileum. To Statistical analysis was used orthogonal contrasts where there were significant differences $(\mathrm{p}<0.05)$ all periods examined and also the different intestinal segments and feature desired (villus height and crypt depth).
\end{abstract}

Key words: Feed conversion. Feed Intake. Food. Nutrition. Weight gain. 


\section{INTRODUÇÃO}

O termo microbiota é usado para descrever a população bacteriana que habita o intestino. Ela forma um sistema complexo e dinâmico responsável por fatores imunológicos, microbiológicos, fisiológicos e bioquímicos do animal (TANNOCK, 1998).

A microbiota também auxilia no processo digestório, ajudando o metabolismo de carboidratos, aumentando a digestão do amido, metabolismo de proteínas, lipídeos e minerais, na síntese de vitaminas e digestão cecal dos componentes fibrosos. Quando a microbiota encontra-se equilibrada, ela contribui indiretamente com a exclusão e/ou competição com bactérias patogênicas (ITO et al., 2004).

O tipo de alimento fornecido para os animais determina variações morfológicas intestinais, sendo as características físicas e químicas responsáveis por modificarem a integridade das células epiteliais da mucosa do trato digestivo (KLASING, 1998).

Aves recém-nascidas possuem pouca diversidade em sua microbiota intestinal, e este fato se torna limitante para a digestão e proliferação de patógenos entéricos. A falta de contato com a microbiota natural logo após o nascimento pode afetar o desenvolvimento do trato gastrointestinal e acabar prejudicando o desenvolvimento desse animal. Estes efeitos negativos vêm sendo minimizados pelo uso de aditivos na alimentação das aves, que auxiliam a melhora do trato gastrointestinal, bem como o desempenho dos animais (MAIORKA et al., 2001). 


\section{MATERIAL E MÉTODOS}

\subsection{LOCAL, INSTALAÇÕES E PERÍODO EXPERIMENTAL}

O experimento foi realizado no aviário experimental do Departamento de Nutrição e Produção Animal da Faculdade de Medicina Veterinária e Zootecnia da Universidade de São Paulo, Campus Pirassununga, Estado de São Paulo, em galpão de alvenaria dividido em 36 boxes de 4,25 $\mathrm{m}^{2}$ cada, sendo a criação das aves feita em piso, no período de 22 de junho de 2010 a 02 de agosto de 2010, em um total de 42 dias.

As lâminas histológicas foram preparadas no Laboratório de Citologia e Imunohistoquímica no Departamento de Ciências Básicas da Universidade de São PauloFaculdade de Zootecnia e Engenharia de Alimentos.

A morfometria foi realizada no Laboratório de Morfofisiologia Molecular e Desenvolvimento pertencente ao Departamento de Ciências Básicas da Faculdade de Zootecnia e Engenharia de Alimentos da Universidade de São Paulo.

\subsection{ANIMAIS}

Foram utilizados 108 pintos no período de 1 a 42 dias de idade da linhagem comercial Cobb, comercializados do incubatório Globoaves.

\subsection{DIETA EXPERIMENTAL, DELINEAMENTO E TRATAMENTOS}

A ração foi diferenciada quanto aos níveis de proteína e energia em três fases de desenvolvimento, para atender as exigências nutricionais de cada intervalo de criação: inicial (1 a 21 dias), crescimento (22 a 35 dias) e final (36 a 42 dias). 
As aves foram alojadas de acordo com um delineamento inteiramente casualizado e distribuídos em seis diferentes tratamentos de acordo com a tabela 2, capítulo II, com seis repetições (boxes) por tratamento, com 40 aves cada.

O grupo controle era composto apenas da dieta basal sem qualquer aditivo promotor de crescimento.

O grupo tratado com antibiótico foi suplementado com bacitracina de zinco na dose de $500 \mathrm{~g} / \mathrm{ton}$ de ração. O produto foi utilizado durante toda a fase de criação e era na forma de pó.

O grupo tratado com prebiótico (MOS) composto $100 \%$ de parede celular de levedura Saccharomyces cerevisae, rico em mananoligossacarídeos e beta-glucanos, comercializado sob o nome Immunowall pela empresa ICC foi adicionado à dieta na dose $1 \mathrm{~kg} /$ ton de ração.

O grupo tratado com a mistura de ácidos orgânicos, comercialmente chamado de Premium Sal. Ácido 4 da empresa Nutriacid e sua composição básica composta de ácido benzóico 58\%, ácido fórmico, ácido cítrico, água e silicatos foi suplementado com 1,5kg/ton de ração em pó nas duas primeiras fases de criação (1à 21 dias e de 22 à 35 dias) e com $1 \mathrm{~kg} /$ ton de ração na última fase de criação (36 à 42 dias).

O grupo tratado com extratos de plantas comercialmente conhecido por XTRACT da empresa Evonik Degussa que em sua composição apresenta carvacol, cinamaldeído, capsicum oleoresin/ sólido (pó) laranja claro, foi suplementado com 150g/ton de ração no período inicial de criação (1 à 21dias), com 120g/ton de ração no período de crescimento (22 à 35 dias) e com 100g/ton de ração no período final (36 à 42 dias).

O grupo tratado com a associação do ácido + Mos foi suplementado com 1kg/ton de ração de MOS + 1,5kg/t de ração de ácido no nos períodos (1 à 21 e 22 à 35 dias) e com 1kg/ton de ração de MOS + 1kg/ton de ácido no período (36 à 42 dias).

Todos os aditivos foram utilizados de acordo com as recomendações do fabricante e adicionados em substituição ao equivalente em peso de material inerte (caolim), ajustando-se as composições percentuais das diferentes rações experimentais.

Os tratamentos não foram submetidos a qualquer anticoccidiano ou aditivos diferentes dos citados anteriormente.

Na tabela 3 do Capítulo II, estão os valores nutricionais dos ingredientes e a composição calculada nos períodos de criação, além das dosagens dos diferentes aditivos estudados.

\subsection{MANEJO DOS ANIMAIS}


O manuseio dos pintinhos foi cuidadoso, liberando-os junto às fontes de aquecimento, bebedouro e comedouro. Aquecedores (campânulas) foram ligados antes da chegada das aves para estabilizar a temperatura, aquecer a cama onde as aves permaneceram durante toda a criação. O manejo das cortinas foi feita para uma boa ventilação e iluminação do galpão, bem como a limpeza e nível adequado de água e ração nos bebedouros e comedouros. A limpeza dos bebedouros não foi feita diariamente, tendo dias intercalados para que o desafio fosse aumentado.

A ração foi fornecida ad libitum nos comedouros tipo tubular. A cama era reutilizada e de casca de arroz, com o intuito de aumentar o desafio sanitário.

As aves foram pesadas no primeiro dia do experimento e ao final de cada período de criação (aos 21, 35 e aos 42 dias de idade). Todas as aves foram vacinadas no galpão e individualmente, contra a doença de Newcastle via ocular.

\subsection{PARÂMETROS AVALIADOS}

Utilizando a metodologia descrita por Oliveira et al. (2000), foram coletados fragmentos do intestino delgado (duodeno, jejuno e íleo) aos 21, 35 e 42 dias de idade, com aproximadamente $1 \mathrm{~cm}$ de comprimento, sendo seis animais por tratamento (um por repetição), totalizando 36 animais por período, para a análise da morfologia intestinal através da microscopia de luz.

O abate foi feito por deslocamento cervical e após a retirada dos fragmentos foram lavados com água deionizada cuidadosamente para não agredir as vilosidades, e fixados em Bouin por 24 horas, após este período as amostras foram reduzidas e o Bouin foi substituído por álcool $70 \%$ para desidratação. Depois, diafanizados, impregnados em xilol e incluídos em parafina. Cada bloco possuía todas as repetições daquele tratamento e do respectivo fragmento intestinal (Figura 1).

Foram feitos cortes histológicos (Figura 2), com seis micrômetros de espessura, sendo três cortes simi-seriados de cada bloco. Após o corte foram colocados em lâminas e corados com hematoxilina-eosina de Harris para mensuração da altura dos vilos e profundidade das criptas. 


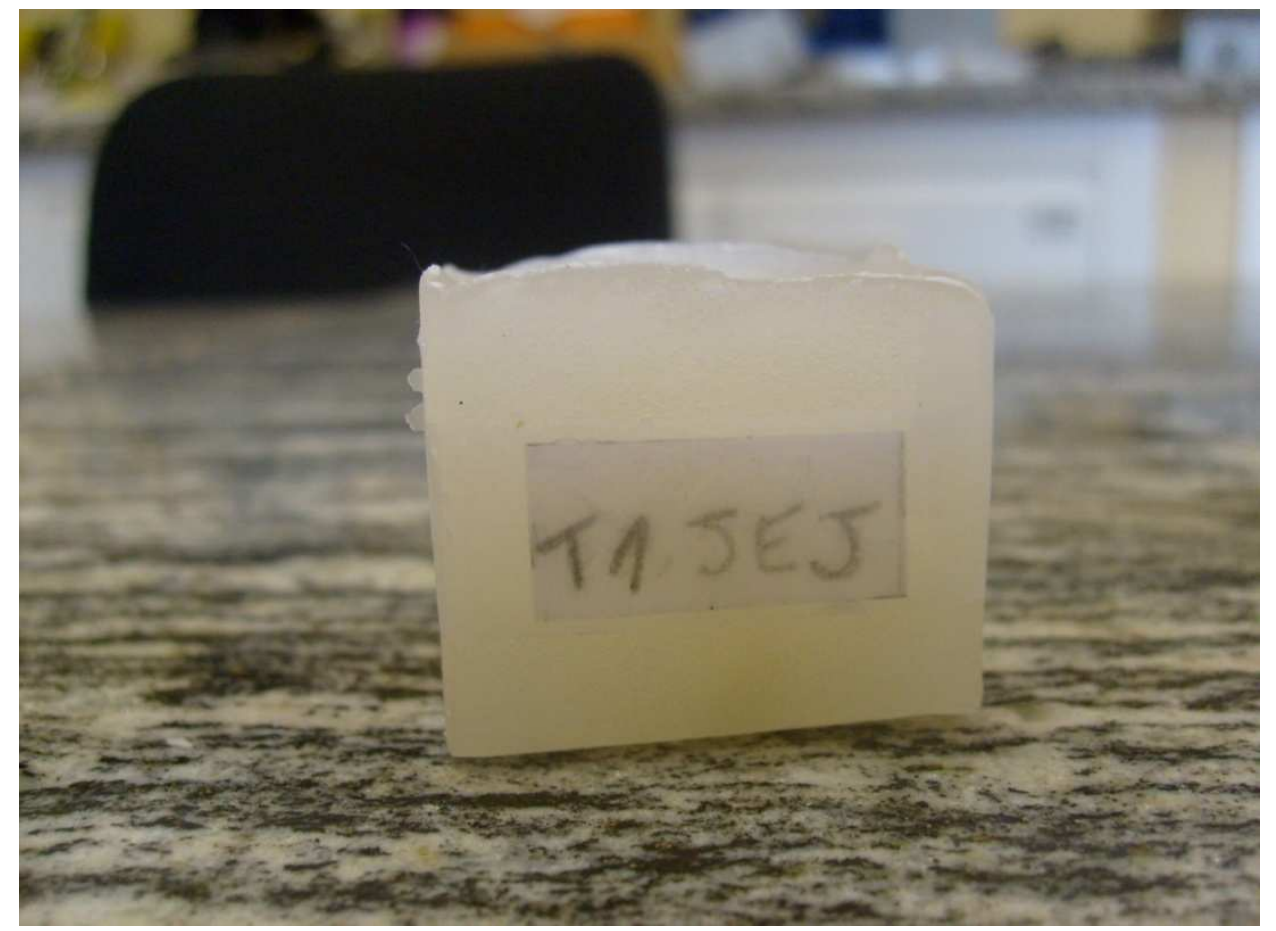

Figura 1- Bloco de parafina com os segmentos intestinais do jejuno

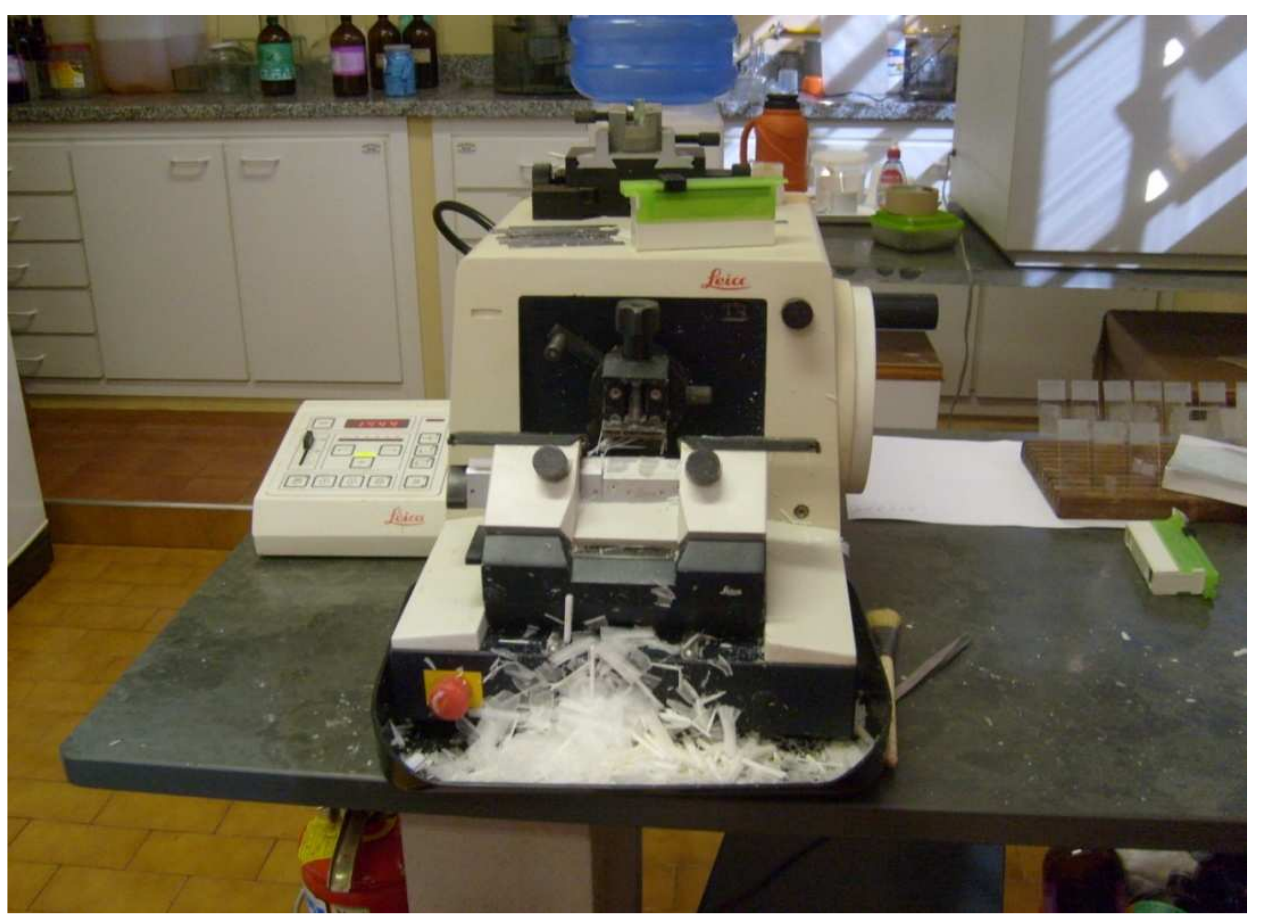

Figura 2 - Máquina para cortes histológicos 
Para a morfometria, utilizou-se o microscópio de luz Zeiss Axioplan 2 integrado à câmara digital e ao software AxioVision 4. Foram feitas trinta medias de altura de vilos e trinta para profundidade de criptas para cada lâmina, com aumento de 5x@1388 (Figuras 3 e 4).

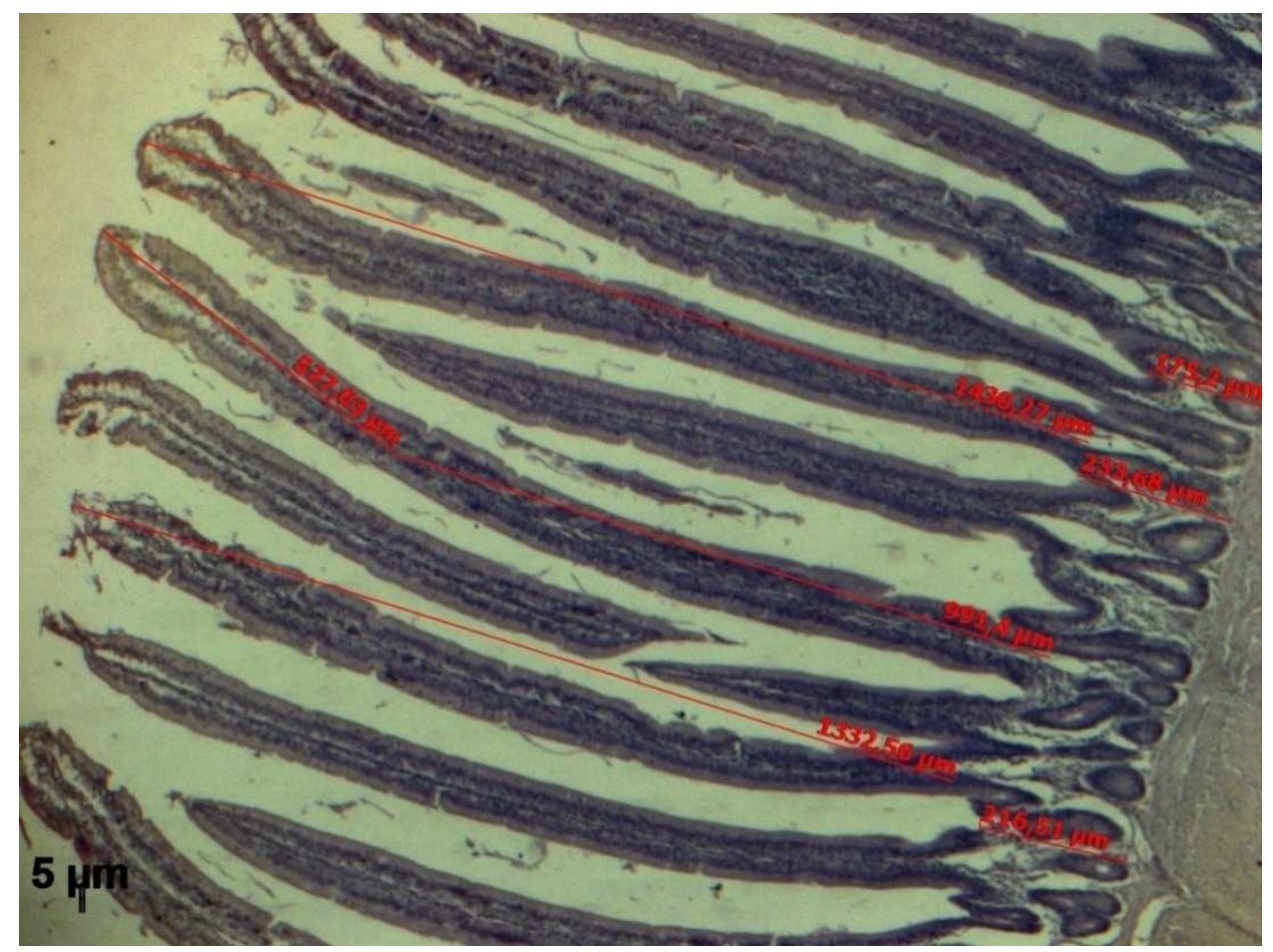

Figura 3 - Altura de vilos e profundidade de cripta no jejuno aos 35 dias de idade 


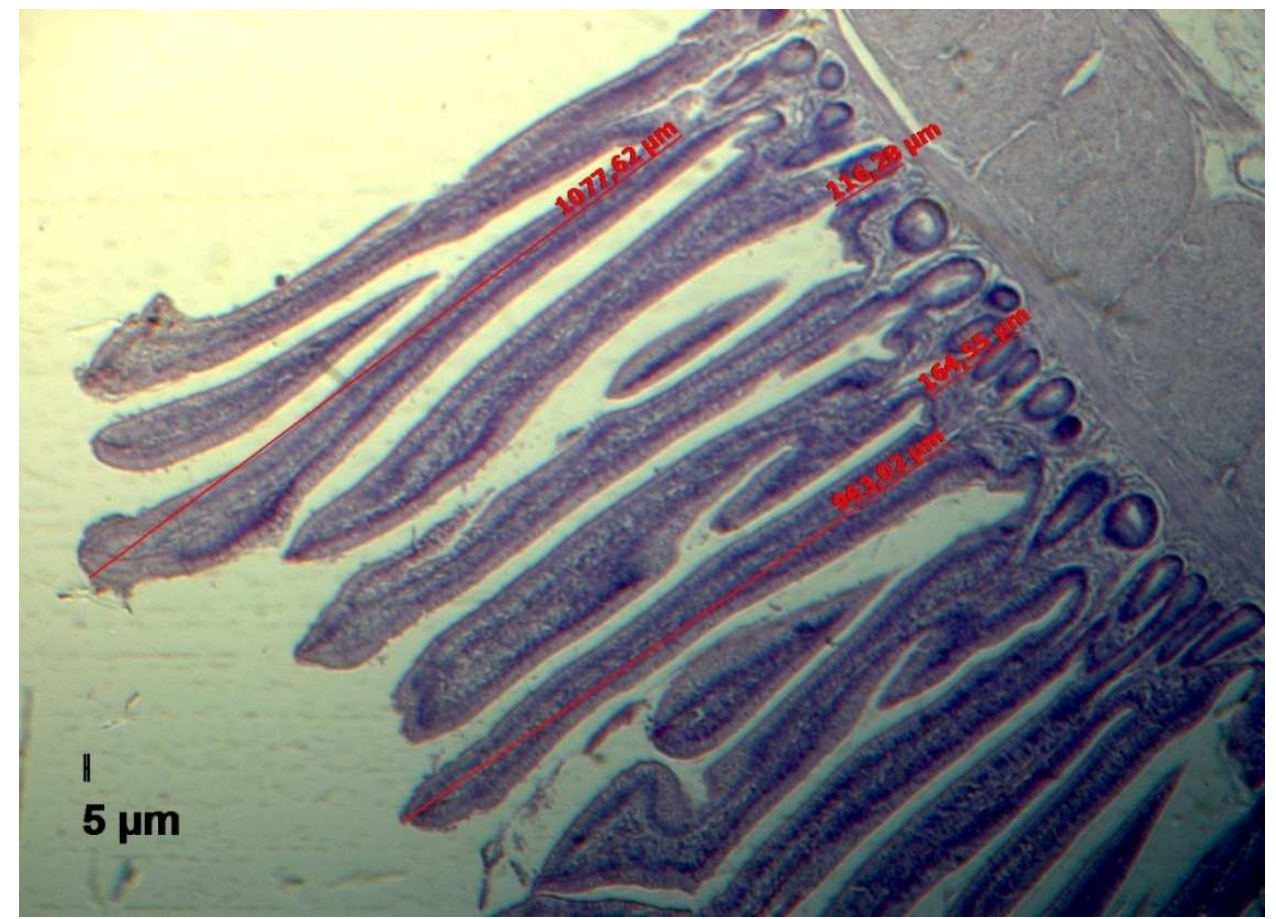

Figura 4 - Altura de vilos e profundidade de cripta no íleo aos 42 dias

\subsection{ANÁLISE ESTATÍSTICA}

A estatística utilizada foi a mesma descrita no item 6.7 do Capítulo II. 


\section{RESULTADOS E DISCUSSÃO}

Os resultados de altura de vilos e profundidade de cripta de frangos de corte alimentados com diferentes aditivos no final de cada período ( 21 dias, 35 dias, e 42 dias) de idade e as análises dos contrastes estão descritos na tabela 1.

Através dos desdobramentos dos contrastes foi possível observar efeito significativo dos diferentes aditivos em relação ao antibiótico e também ao grupo controle. 
Tabela 6 - Altura de vilos e profundidade de cripta do duodeno, jejuno e íleo e seus contrastes com os níveis de significância para cada variável em 21,35 e 42 dias de idade

\begin{tabular}{|c|c|c|c|c|c|c|c|c|c|c|c|c|}
\hline \multirow{2}{*}{ Parâmetros } & \multicolumn{7}{|c|}{ Tratamentos } & \multicolumn{5}{|c|}{ Probabilidades ${ }^{I}$} \\
\hline & CRONTROLE & ANTIBIÓTICO & MOS & ÁC. ORG. & MÓS+ÁC. ORG. & EXT. PLANTA & $\mathrm{CV}(\%)$ & $\mathrm{C} 1$ & $\mathrm{C} 2$ & $\mathrm{C} 3$ & $\mathrm{C} 4$ & $\mathrm{C} 5$ \\
\hline \multicolumn{13}{|c|}{ Altura de Vilos $\mu$ (21 dias) } \\
\hline Duodeno & 1108,31 & 801,29 & 1443,44 & 1394,99 & 1582,24 & 1465,28 & 33,77 & 0,0003 & $<0,001$ & 0,9340 & 0,2667 & 0,1282 \\
\hline Jejuno & 1144,60 & 1206,98 & 929,89 & 885,01 & 1196,87 & 1536,51 & 29,25 & 0,928 & 0,361 & $<0,0001$ & 0,007 & 0,001 \\
\hline Íleo & 917,08 & 832,76 & 771,51 & 724,45 & 1053,76 & 989,69 & 23,57 & 0,529 & 0,310 & 0,009 & $<0,0001$ & $<0,0001$ \\
\hline \multicolumn{13}{|c|}{ Prof. Cripta $\mu$ (21 dias) } \\
\hline Duodeno & 290,45 & 304,00 & 287,56 & 193,22 & 270,68 & 303,10 & 24,89 & 0,1158 & 0,0192 & 0,0035 & 0,4306 & 0,0005 \\
\hline Jejuno & 287,75 & 224,14 & 366,61 & 296,30 & 286,21 & 300,68 & 29,24 & 0,2987 & 0,0002 & 0,4971 & 0,0057 & 0,7211 \\
\hline Íleo & 211,98 & 154,23 & 254,55 & 197,65 & 213,94 & 249,35 & 27,45 & 0,2093 & $<0,0001$ & 0,0513 & 0,0187 & 0,3376 \\
\hline \multicolumn{13}{|c|}{ Altura de Vilos $\mu$ (35 dias) } \\
\hline Duodeno & 1163,35 & 1189,95 & 1423,91 & 1626,99 & 1354,20 & 1445,26 & 21,87 & $<0,0001$ & 0,0003 & 0,7573 & 0,4902 & 0,0085 \\
\hline Jejuno & 1086,51 & 1086,75 & 1245,55 & 1186,44 & 1381,35 & 1361,52 & 19,73 & 0,0008 & 0,0009 & 0,1555 & 0,0744 & 0,0114 \\
\hline Íleo & 857,23 & 942,85 & 1009,72 & 1028,68 & 1124,06 & 1112,75 & 18,32 & $<0,0001$ & 0,0127 & 0,2075 & 0,0465 & 0,0953 \\
\hline \multicolumn{13}{|c|}{ Prof. Cripta $\mu$ (35 dias) } \\
\hline Duodeno & 249,12 & 342,72 & 372,92 & 266,38 & 358,54 & 323,74 & 30,57 & 0,0011 & 0,6069 & 0,7219 & 0,6695 & 0,0078 \\
\hline Jejuno & 258,10 & 507,24 & 253,50 & 306,49 & 220,28 & 275,17 & 62,86 & 0,9074 & $<0,0001$ & 0,7681 & 0,6015 & 0,1703 \\
\hline Íleo & 195,90 & 183,30 & 143,55 & 169,80 & 179,96 & 160,99 & 25,57 & 0,0093 & 0,1072 & 0,7831 & 0,0200 & 0,5086 \\
\hline \multicolumn{13}{|c|}{ Altura de Vilos $\mu$ (42 dias) } \\
\hline Duodeno & 1644,00 & 42,67 & 00,91 & 1832,74 & 746,89 & 1852,00 & 16,30 & 0,1325 & 0,1281 & 0,1106 & 0,1283 & 0,3685 \\
\hline Jejuno & 1568,57 & 1531,29 & 1479,46 & 1566,03 & 1779,30 & 1653,94 & 15,09 & 0,3742 & 0,1264 & 0,4416 & $<0,0001$ & 0,0043 \\
\hline Íleo & 1129,02 & 1169,32 & 1331,33 & 1328,42 & 1320,59 & 1225,68 & 14,74 & 0,0008 & 0,0262 & 0,0499 & 0,8629 & 0,8998 \\
\hline \multicolumn{13}{|c|}{ Prof. Cripta $\mu$ (42 dias) } \\
\hline Duodeno & 238,66 & 263,44 & 289,39 & 254,26 & 265,70 & 282,16 & 20,89 & 0,0328 & 0,5498 & 0,4481 & 0,2373 & 0,5665 \\
\hline Jejuno & 366,85 & 308,36 & 311,22 & 247,90 & 258,53 & 296,33 & 25,79 & $<0,0001$ & 0,1324 & 0,2449 & 0,0402 & 0,6691 \\
\hline Íleo & 133,33 & 188,21 & 232,35 & 184,46 & 151,44 & 158,31 & 32,68 & 0,0009 & 0,6894 & 0,0334 & $<0,0001$ & 0,0633 \\
\hline
\end{tabular}

C.V.- Coeficiente de variação

1- $\mathrm{C} 1=$ controle vs aditivos; $\mathrm{C} 2=$ antibiótico VS aditivos; $\mathrm{C} 3=$ extratos de plantas VS aditivos; $\mathrm{C} 4=\mathrm{MOS}$ vs MOS+ ácidos orgânicos; C5= ácidos orgânicos vs MOS+ ácidos orgânicos 
No contraste 1 , houve diferença significativa $(\mathrm{p}<0,05)$ aos 21 dias de idade, onde o controle negativo apresentou menor altura de vilo em relação aos demais aditivos na região duodenal. Para o contraste 2 a mesma diferença foi encontrada, já para os demais aditivos não foram encontradas diferenças. Em relação a profundidade de cripta neste mesmo segmento do intestino delgado, verificou-se efeito significativo através do contraste 3 , tendo o tratamento com extratos de plantas maior profundidade de cripta em relação aos demais aditivos. No contraste 5, onde a comparação feita é entre a associação de MOS+ ÁC. ORG. e o uso de ácidos orgânicos isoladamente, mostra que a associação teve maior profundidade de cripta. Ainda aos 21 dias de idade, na região jejunal os resultados encontrados para altura de vilo foram entre os diferentes aditivos. Através do contraste 3 o efeito significativo foi demonstrado pela maior altura de vilos do tratamento com extratos de plantas em relação aos demais aditivos. Nos contrastes 4 e 5 os efeitos foram significativos e o tratamento com a associação dos aditivos teve maior altura de vilo em relação aos aditivos isolados. Para profundidade de cripta desta região a diferença apareceu entre o tratamento com antibiótico e os demais aditivos, tendo, o antibiótico menor profundidade de cripta. Já no contraste 4, o uso de Mos isolado teve maior profundidade de cripta em relação à associação.

$\mathrm{Na}$ porção final do intestino delgado também aos 21 dias, os contraste 1 e 2 não apresentaram diferenças significativas para altura de vilo, porém para profundidade de cripta o tratamento controle obteve menores medidas em comparação aos diferentes aditivos alternativos. Os contrastes 3, 4 e 5 apresentaram diferenças significativas, tendo o extrato de plantas maior altura de vilos.

Salazar (2006) discorda dos resultados encontrados, pois trabalhando com ácidos orgânicos isolados e associados não encontrou efeito significativo para altura de vilo e nem entre cripta:vilo no duodeno, porém para profundidade de cripta encontrou maiores medidas para o grupo com antibiótico, na região ileal o efeito encontrado foi do tipo aditivo para o tratamento associado em relação ao ácido isolado. Também discordando dos resultados do estudo (SILVA et al., 2000), utilizando aditivos não obtiveram diferença significativa aos 21 e 42 dias de idade das aves, para altura de vilo e profundidade de cripta, concluindo que os aditivos não interferiam na morfologia da mucosa intestinal.

Furlan, Macari e Luquetti (2004), trabalhando com MOS observaram aumento significativo na altura de vilo no duodeno, jejuno e íleo, sendo mais evidentes, na primeira semana de vida das aves, eles explicam este fato do aumento da altura de vilos em frangos de corte no duodeno se manifestar in ovo do $17^{\circ}$ dia de incubação até o $7^{\circ}$ dia pós- eclosão e completam afirmando que os aditivos agem como agentes tróficos na mucosa intestinal, pois 
fazem o processo de mitose na célula aumentar entre a cripta e o vilo, e com isso aumentar o número de células e o tamanho do vilo.

Segundo Boratto et al. (2004), não houve efeito significativo ( $p>0,05)$, para nenhum dos parâmetros avaliados que foi altura de vilo, profundidade de cripta e relação cripta/vilo entre a interação dos tratamentos.

Aos 35 dias de idade através do desdobramento do contraste 1 pode-se notar efeito significativo no duodeno para altura de vilos, tendo o tratamento controle menor altura de vilos, atrelado a este resultado está a profundidade de cripta que também apresentou diferença significativa, onde a associação de aditivos teve menor profundidade de cripta que o ácido orgânico isolado. Para o contraste 2 o efeito foi o mesmo, menor altura de vilos frente aos demais aditivos. Entre os diferentes aditivos o contraste 5 prova que a utilização de ácido orgânico isolado teve maior altura de vilo em relação à associação, atrelado a este resultado está o efeito significativo para profundidade de cripta tendo o ácido isolado maior valor mensurado.

$\mathrm{Na}$ região jejunal as diferenças significativas foram observadas através do contraste 1 , tendo mais uma vez o tratamento controle menor altura de vilos. E no contraste 2 o mesmo efeito foi encontrado para altura de vilos, porém obteve maior profundiade de cripta. Como no segmento anterior o contraste 5 apresentou efeito significativo, a associação teve maior altura de vilo. No íleo, o contraste 1 apresentou menor altura de vilos porém, para profundidade de cripta o efeito encontrado foi menor em relação aos demais aditivos. No contraste 2 a maior altura de vilos foi para os diferentes aditivos em relação ao antibiótico. A associação de aditivos teve maior altura de vilos em relação ao MOS isolado através do contraste $4 \mathrm{e}$ também maior profundidade de cripta. Concordando com estes resultados Murarolli (2008), observou efeito significativo no tratamento com antibiótico, causando diminuição na altura de vilos no jejuno, para a região ileal houve efeito na interação dos aditivos apresentando menor altura de vilo e menor profundidade de cripta do duodeno em relação à soma dos efeitos de prebiótico e probiótico isoladamente.

Através da digestão e absorção de nutrientes ocorrem perdas de áreas na mucosa intestinal, seja por lesão ou por ação de patógenos, e o epitélio excedente tem um aumento considerável no número de células, com isso maior altura de vilos e profundidade de cripta ajudando assim a melhora da absorção de nutrientes. Porém esta absorção só ocorre de fato se as células tiverem sua integridade funcional preservada, pois este aumento de células na cripta pode acarretar no aparecimento de enterócitos não funcionais que tem baixa capacidade absortiva e enzimática. Considerando estes fatos, Maiorka (2002), afirma que a maior altura de vilo está 
intimamente ligada a maior absorção de nutrientes e quanto menor a contaminação por agentes patogênicos, maior será o crescimento destas vilosidades.

A proliferação das células na base do vilo para o ápice onde sofrem descamação tendo equilíbrio de renovação e algumas perdas são conhecidas como turnover celular. Randall et al. (2000). Esta renovação ocorre devido a processos mitóticos pelas células que ficam ao longo das vilosidades (UNI et al., 1998).

Segundo Pluske et al. (1997) e Luquetti (2005), a maior profundidade de cripta acontece devido ao processo mitótico na tentativa de reparar a mucosa à medida que os vilos são destruídos, e isto indica boa atividade de renovação epitelial por haver necessidade de reconstrução tecidual. Frente a isto, Viola e Vieira (2007), discordam dizendo que menores profundidades de cripta indicam melhor saúde intestinal e também observaram que utilizando antibióticos e ácidos orgânicos o efeito foi similar para ambos, menor colonização de patógenos melhorando assim a mucosa intestinal e suas vilosidades através de reduzidas perdas por descamação, aumento de células nas criptas por esta agir como energia para os enterócitos, tendo assim maior altura de vilo e melhor aproveitamento dos nutrientes. Nabuurs (1995) concorda afirmando que a melhor relação é quando as vilosidades são altas e as criptas apresentam-se rasas.

No entanto Silva et al. (2008), utilizando MOS e antibiótico através da microscopia eletrônica de varredura analisando segmentos do intestino delgado, puderam observar diferença significativa na organização das vilosidades e nas formas que permaneciam íntegras. Já Nunes (2008) utilizando prebióticos e antibióticos não encontrou nenhum efeito significativo para os parâmetros morfológicos avaliados nos três segmentos intestinais, pois considerava que o efeito se daria relacionando os parâmetros analisados.

Macari e Maiorka (2000), observaram maior altura de vilos no duodeno, jejuno e íleo trabalhando com parede de Saccharomices cerevisae.

Barbosa (2009), estudando o uso de MOS pode observar diferença significativa na relação cripta:vilo do seguimento ileal aos 21 dias de idade, tendo o tratamento com antibiótico maiores valores. No jejuno aos 42 dias de idade houve efeito para os tratamentos com MOS e antibiótico, apresentando maior profundidade de cripta em relação ao controle e maior altura de vilos para o tratamento com MOS.

Pelicano et al. (2003), encontraram menores profundidades de cripta nas 3 porções intestinais, porém para altura de vilo não houve efeito. Gunal et al. (2006), utilizando antibióticos e ácidos orgânicos também não encontraram diferenças significativas na altura das vilosidades durante o período experimental. 
No final do período de criação não houve diferença significativa para altura de vilos na região duodenal, porém para profundidade de cripta o tratamento controle diferiu dos diferentes aditivos utilizados. Já na região do jejuno a diferença encontrada foi para o contraste 4, o MOS isolado obteve maior altura de vilos e maior profundidade de cripta comparado à associação de aditivos. No contraste 5 a associação de aditivos teve aumento nas vilosidades em relação ao ácido isolado. Na porção final do intestino delgado os efeitos significativos encontrados foram para os contrastes 1 e 2 que continuaram com o mesmo padrão dos períodos anteriores, tendo menor altura de vilos em relação aos diferentes aditivos e também menor profundidade de cripta no contraste 1. Entre os aditivos o efeito significativo $(\mathrm{p}<0,05)$ foi para o contraste 3, onde o tratamento com extratos de plantas obteve menor altura de vilos e menor profundidade de cripta, o que não vinha ocorrendo nos demais períodos e segmentos intestinais. 


\section{CONCLUSÃO}

Os diferentes aditivos promoveram melhorias na qualidade dos vilos, e profundidade de cripta em comparação a utilização do antibiótico, sendo uma eficiente alternativa de uso. 


\section{REFERENCIAS}

BARBOSA, N. A. R. Avaliação de aditivos em dietas de frangos de corte. 2009. 166 f. Tese (Doutorado em Zootecnia) - Faculdade de Ciências Agrárias e Veterinárias, Universidade Estadual Paulista, Jaboticabal. 2009.

BORATTO, A. J.; LOPES, D. C.; OLIVEIRA, R. F. M.; ALBINO, L. F. T.; MORAES SÁ, L.; OliveIRA, G. A. Uso de Antibiótico, de Probiótico e de Homeopatia, em Frangos de Corte Criados em Ambiente de Conforto, Inoculados ou não com Escherichia coli. Revista Brasileira de Zootecnia, v. 33, n. 6, p. 1477-1485, 2004.

FURLAN, R. L.; MACARI, M.; LUQUETTI, B. C. Como avaliar os efeitos do uso de prebióticos, probióticos e flora de exclusão competitiva. In: SIMPOSIO TÉCNICO DE INCUBAÇÃO, MATRIZES DE CORTE E NUTRICAO, 5., 2004, Balneário Camboriú. | Anais... Balneário Camboriú, 2004. p. 6-28.

GUNAL, M.; YAYLI, G.; KAYA, O.; KARAHAN, N.; SULAK, O. The Effects of Antibiotic Growth Promoter, Probiotic or Organic Acid Supplementation on Performance, Intestinal Microflora and Tissue of Broilers. International Journal of Poultry Science, v. 5, n. 2, p. 149-155, 2006.

ITO, N. M. K.; MIYAJI, C. I.; LIMA, E. A.; OKABAYASHI, S. O. Saúde gastrointestinal, manejo para controlar as enfermidades gastrointestinais. In: MENDES, A. A.; NASS, I. A.; MACARI, M. Produção de frangos de corte. Campinas, SP.: Editora FACTA, 2004. p. 205260 .

KLASING, K._G. Nutricional modulation of resistence to infections disease. Poultry Science, Champaign, v. 77, p. 1119-1125, 1998.

LUQUETTI, B. C. Efeito da vacinação contra coccidiose aviária e da suplementação de glutamina ou prebiótico sobre a mucosa intestinal em frangos. 2005. $106 \mathrm{f}$. Tese (Doutorado em Zootecnia) - Faculdade de Ciências Agrárias e Veterinárias, Universidade Estadual Paulista, Jaboticabal, 2005.

MACARI, M.; MAIORKA, A. Função gastrintestinal e seu impacto no rendimento avícola. In: CONFERÊNCIA APINCO DE CIÊNCIA E TECNOLOGIA A VÍCOLAS, 2000, Campinas. Anais... Campinas: FACTA, 2000. v. 2, p. 161-174.

MAIORKA, A.; SANTIN, E.; SUGETA, S. M.; ALMEIDA, J. G.; MACARI, M. Utilização de prebiótico, probiótico ou simbiótico em dietas para frangos. Revista Brasileira de Ciência Avícola, v. 3, n.1, p. 75- 82, 2001.

MAIORKA, A. Efeito da idade da matriz, do jejum, da energia da ração e da glutamina sobre o desenvolvimento da mucosa intestinal e atividade enzimática do pâncreas de pintos de corte. 2002. 103 p. Tese (Doutorado em Zootecnia) - Faculdade de Ciências Agrárias e Veterinária, Universidade Estadual Paulista, Jaboticabal, 2002.

MURAROLLI, V. D. A. Efeito de prebiótico, probiótico e simbiótico sobre o desempenho, morfologia intestinal e imunidade de frangos de corte. 2008. $101 \mathrm{f}$. 
Dissertação (Mestrado em Medicina Veterinária) - Faculdade Medicina Veterinária e Zootecnia, Universidade de São Paulo, Pirassununga, 2008.

NABUURS, M. J. A. Microbiological, structural and functional changes of the small intestine of pigs at weaning. Pigs News Information, v. 16, n. 3, p. 93-97, 1995.

NUNES, A. D. Influência do uso de aditivos alternativos a antimicrobianos sobre o desempenho, morfologia intestinal e imunidade de frangos de corte. $2008.111 \mathrm{f}$. Dissertação (Mestrado em Medicina Veterinária) - Faculdade Medicina Veterinária e Zootecnia, Universidade de São Paulo, Pirassununga, 2008.

OLIVEIRA, P. B.; MURAKAMI, A. E.; GARCIA, E. R. M.; MACARI, M.; SCAPINELLO, C. Influência de fatores antinutricionais da Leucena (Leucaena leucocephala e Leucaena cunningan) e do Feijão Guandu (Cajanus cajan) sobre o epitélio intestinal e o desempenho de frangos de corte. Revista Brasileira de Zootecnia, v. 29, n. 6, p. 1759-1769, 2000.

PELICANO, E. R. L.; SOUZA, P. A.; SOUZA, H. B. A.; OBA, A.; NORKUS, E. A.; KODAWARA, L. M.; LIMA, T. M. A. Morfometria e Ultra-Estrutura da Mucosa Intestinal de Frangos de Corte alimentados com Dietas contendo diferentes Probióticos. Revista Portuguesa de Ciência Avícola, v. 98, n. 547, p. 125-134, 2003.

PLUSKE, J. R.; HAMPSON, D. J.; WILLIAMS, I. H. Factors influencing the structure and function of the small intestine en the weaned pig: a review. Livestock Production Science, v. 51, p. 215-236, 1997.

RANDALL, D.; BUGGEN W.; FRENCH, K. In: adaptações. Rio de Janeiro, 2000. p. 582-518.

Fisiologia animal: mecanismo de

SALAZAR, P. C. R. Efeito dos ácidos lático e butírico, isolados e associados, sobre o

desempenho, imunidade humoral e morfometria intestinal em frangos de corte. 2006. 72 f. Dissertação (Mestrado em Medicina Veterinária) - Faculdade Medicina Veterinária e Zootecnia, Universidade de São Paulo, Pirassununga, 2006.

SILVA, E. N.; TEIXEIRA, A. S.; FIALHO, E. T.; BERTECHINI, A. G.; SOUZA, P. R. I. Efeitos dos probióticos e antibióticos sobre as vilosidades e $\mathrm{pH}$ do trato gastrointestinal de frangos de corte. Ciência Agrotécnica, Lavras, v. 24, p. 163-173, 2000. (Edição Especial).

SILVA, C. J.; VARGAS JR., F. M.; SILVA, I. S.; ARIAS, E. R. A.; CARRIJO, A. S.; GARCIA, R. G.; GOMES, R. F. Uso de prebiótico (Bio-Mos $\left.{ }^{\circledR}\right)$ associado a diferentes níveis protéicos em rações de frango de corte. Agrarian, v. 1, n. 1, p. 105-116, 2008.

TANNOCK, G. W. Studies of the intestinal microflora: a prerequisite for the development of probiotics. International Dairy Journal, Huntington, v.8, n.5/6, p.527- 533, 1998.

UNI, Z.; GANOT, S.; SKLAN, D. Post hatch development of mucosal function in the broiler small intestine. Poultry Science, v.77, p. 75-82, 1998.

VIOLA, E. S.; VIEIRA, S. L. Suplementação de acidificantes orgânicos e inorgânicos em dietas para frangos de corte: desempenho zootécnico e morfologia intestinal. Revista Brasileira de Zootecnia, v. 36, n. 4, p.1097-1104, 2007. Suplemento. 